\title{
SELVITYS AVOIMESTA VERTAISARVIOINNISTA KOTIMAISEN TIEDEJULKAISEMISEN KENTÄLLÄ
}

Riitta Jytilä,Turun yliopisto, Turku

Mikael Laakso,Hanken Svenska handelshögskolan, Helsinki

23.3.2019 
Selvityksen on rahoittanut Informaatiotutkimuksen seura ry Suomen tiedekustantajien liiton apurahan turvin.

Kiitoksemme ITY ry:lle ja Kulttuurintutkimuksen seuralle, jotka ideoivat hankkeen alkuun ja hankkivat rahoituksen. Erityisesti kiitämme Riitta Koikkalaista, Susanna Nykyriä, Noora Hirvosta ja Anna Suorsaa.

Jos haluat viitata tähän julkaisuun, suosittelemme käyttämään seuraavaa muotoa:

Jytilä, R. ja Laakso, M. (2019). Selvitys avoimesta vertaisarvioinnista kotimaisen tiedejulkaisemisen kentällä.Tieteellisten seurain valtuuskunnan verkkojulkaisuja 4.

https://doi.org/ 10.23847/978-952-5995/6-9

isbn $978-952-5995-16-9$

Tämä julkaisu on lisensoitu CC-BY 4.0 lisenssillä.

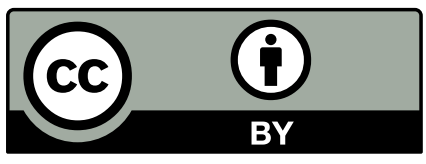

\section{Sisällys}

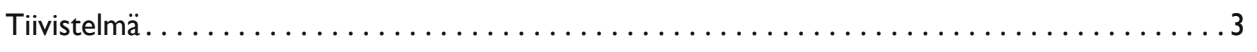
Vertaisarvioinnin muuttuvat käytännöt ja avoimen tieteen kasvupaine $\ldots \ldots \ldots \ldots \ldots \ldots \ldots$

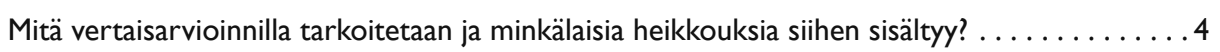

Vertaisarvioinnin uudet muodot ja muutokset $\ldots \ldots \ldots \ldots \ldots \ldots \ldots \ldots \ldots \ldots \ldots \ldots \ldots \ldots \ldots$

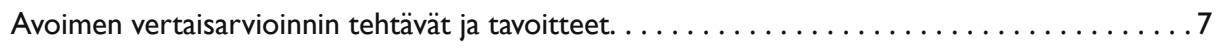

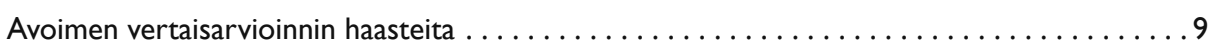

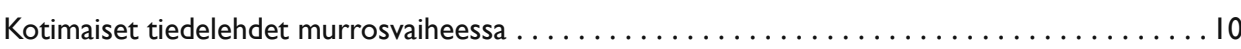

Vertaisarviointi ja tiedeyhteisön merkitys $\ldots \ldots \ldots \ldots \ldots \ldots \ldots \ldots \ldots \ldots \ldots \ldots \ldots$

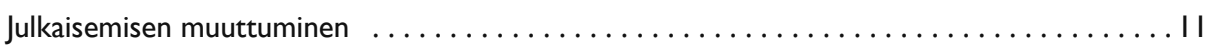

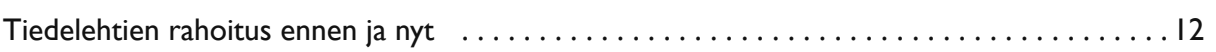

Avoin vertaisarviointi kotimaisen tiedejulkaisemisen kentällä $\ldots \ldots \ldots \ldots \ldots \ldots \ldots \ldots$

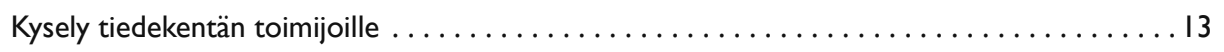

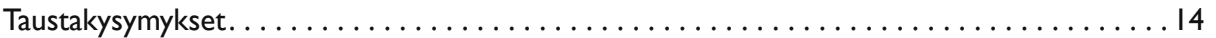

Tyytyväisyys vallitsevaan käytäntöön $\ldots \ldots \ldots \ldots \ldots \ldots \ldots \ldots \ldots \ldots \ldots \ldots \ldots \ldots \ldots \ldots \ldots \ldots \ldots$

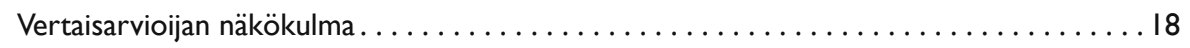

Kirjoittajan näkökulma . . . . . . . . . . . . . . . . . . . . . . . . . . . . 19

Kustantajan näkökulma . . . . . . . . . . . . . . . . . . . . . . . . 19

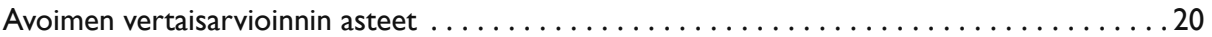

Avoimet vertaisarviolausunnot. . . . . . . . . . . . . . . . . . . . . . . . . 20

Avoimet identiteetit .........................................

Avoin osallistuminen . . . . . . . . . . . . . . . . . . . . . . 22

Avoin vuorovaikutus . . . . . . . . . . . . . . . . . . . . . . . . . . 22

Käsityksiä tieteellisen kommunikaation kentästä suhteessa avoimeen tieteeseen. . . . . 23

Vertaisarvioitujen kirjankustantajien haastattelut . . . . . . . . . . . . . . . . 23

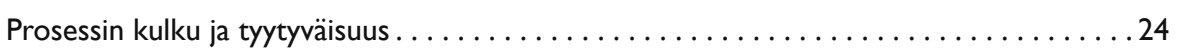

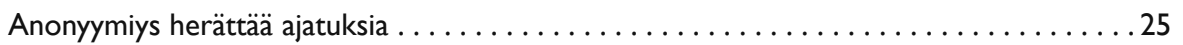

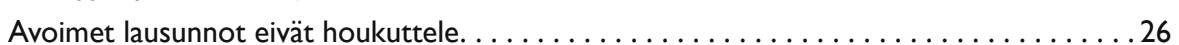

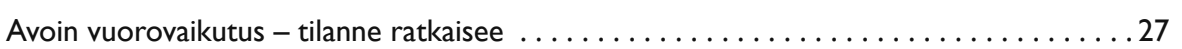

Kaikki vaikuttaa kaikkeen . . . . . . . . . . . . . . . . . . . . . . . . . . . . . . . . . 29

Yhteenveto: avoin vertaisarviointi - hyötyjen ja haasteiden tasapainottelua . . . . . . . . 30 


\section{Tiivistelmä}

\section{Selvityksen tavoitteet}

I. Ottaa selvää tämänhetkisistä vertaisarviointia koskevista käsityksistä

2. Lisätä kotimaisen tiedekentän ymmärrystä avoimesta vertaisarvioinnista nostamalla esiin vertaisarviointia koskevaa kansainvälistä keskustelua

3. Herättää keskustelua erilaisista vertaisarvioinnin prosesseista ja mahdollisuuksista

- Historia, nykyhetken käytännöt ja tulevaisuuden innovaatiot

4. Edistää omalta osaltaan hyvää tieteellistä käytäntöä ja tutkimuksen luotettavuutta

Vertaisarviointiin liittyvien käytäntöjen kehittäminen on yksi keino kiinnittää huomiota ja puolustaa tieteen sisältöjä sekä edesauttaa tieteellistä keskustelua.

Kontekstina avoin tiede. Selvityksessä esitellään kotimaiselle tiedeyhteisölle vertaisarvioinnin muuttuvia käytäntöjä avoimen tieteen kontekstissa. Sekä avoin tiede että vertaisarviointi ovat muuttuvia ja monisyisiä käsitteitä, joiden reunaehtojen tunteminen on tärkeää.Vertaisarvioinnin keskeinen asema tiedemaailmassa näkyy yliopistojen rekrytointiprosesseissa, kilpaillussa tutkimusrahoituksessa sekä julkaisemisen referee-järjestelmässä, jonka tarkastelemiseen tämä selvitys keskittyy. Selvityksen ensimmäinen osa koostuu vertaisarviointia koskevien ajankohtaisten kansainvälisten keskustelujen esittelystä. Sen tarkoitus on auttaa kentän toimijoita löytämään itselle parhaiten sopivia toimintatapoja ja punnitsemaan niiden vaikutuksia. Asenteet ja käytänteet vaihtelevat sekä maantieteellisesti että tieteenalaperinteiden ja -kulttuurien mukaan. Tämän monimuotoisuuden vuoksi on oleellista avata keskustelu siitä, miten eri tavoin avoin vertaisarviointi ymmärretään ja minkälaisena sen vaikuttavuus nähdään.

Kysely ja haastattelut. Selvityksen toisessa osassa esitellään, analysoidaan ja tulkitaan kotimaiselle tiedeyhteisölle kesällä 2018 järjestetyn kyselyn ja kirjankustantajille suunnattujen haastattelujen aineistoa. Kyselyn tavoitteena oli selvittää, miten nykyisen vertaisarviointiprosessin koetaan toimivan: onko kotimainen tiedekenttä tyytyväinen vai tyytymätön vallitseviin käytänteisiin ja miksi. Halusimme kyselyssä nostaa esiin sen, mitä mieltä tiedelehtien tekijät, kirjoittajat ja vertaisarvioijat ovat avoimesta vertaisarvioinnista. Koska lehtien ja kirjojen vertaisarvioprosessit eroavat toisistaan, haastattelimme myös kotimaisia vertaisarviotunnusta käyttäviä kirjankustantajia. Niitä on Suomessa kymmenen: Aalto Arts Books, Eurooppalaisen filosofian seura (niin \& näin -kirjat), Gaudeamus, Vastapaino, Suomalaisen Kirjallisuuden Seura, Lapin yliopistokustannus, Tampere University Press, Into Kustannus, Tutkijaliitto sekä KehräMedia. Haastattelimme kaikkia kustantajia Kehrämediaa lukuun ottamatta. Saimme vastaukset kysymyksiimme kahdeksalta yhdeksästä kustantajasta.

Yhteenveto. Selvityksen tarkoitus ei ole ulkoapäin määritellä kullekin lehdelle sopivia toimintatapoja tai lisätä julkaisuprosessin byrokraattisuutta. Sen sijaan eetoksena on lisätä ymmärrystä vertaisarvioinnin eri keinoista ja käytännöistä erityisesti suhteessa tieteen avoimuuteen. Avointa julkaisemista on monessa yhteydessä edistetty erilaisilla pakotteilla ja vahvoilla kannustimilla. Päätelmämme kerätyn aineiston pohjalta on, että yksinkertaiset ja hyvin yleisen tason linjaukset eivät sovellu kovinkaan hyvin avoimen vertaisarvioinnin edistämiseen. Parasta olisi, jos kukin lehti ja kustantaja arvioisi itse omista lähtökohdistaan sekä lehden erityisten intressien kannalta, mitkä avoimen vertaisarvioinnin osa-alueista kannattaisi ottaa käyttöön. 


\section{Vertaisarvioinnin muuttuvat käytännöt ja avoimen tieteen kasvupaine}

\author{
Mitä vertaisarvioinnilla tarkoitetaan ja minkälaisia heikkouksia \\ siihen sisältyy?
}

Vertaisarvioinnin tarkoitus on palvella tiedeyhteisöä mahdollisimman hyvin. Tavoitteena on, että julkaistavaksi päätyvät riittävän laadukkaat käsikirjoitukset. Vertaisarviointijärjestelmää pidetään tieteellisen julkaisutoiminnan kulmakivenä, ja kaikkine puutteineenkin se on ainoa vallalla oleva julkaistavaksi tarkoitettujen tekstien esitarkastusjärjestelmä (esim. Kovanen \& Saarelma 2002, 277). Historiallisesta perspektiivistä katsottuna vertaisarviointi on ollut keskeinen osa tieteellisen tiedon tuottamista ja julkaisemista jo useamman vuosisadan ajan. Prosessi toimi alkuun tieteellisten seurojen sisällä, mutta on sittemmin tieteen tekemisen laajentumisen ja julkaisemisen kansainvälistymisen myötä levinnyt myös niiden ulkopuolelle (Tennant et al. 2017)

Referee-käytäntö alkoi kehittyä Royal Societyn piirissä 1660-luvulta lähtien.Vertaisarviointi sellaisessa muodossa kuin sen nyt tunnemme, on vakiintunut toisen maailmansodan jälkeen (Ware 2008). On kuitenkin hämmästyttävää, kuinka vähän tiedemaailma on kiinnittänyt vertaisarviointiin huomiota. On kyllä esitetty, että yliopistojen pitäisi ottaa haltuunsa tieteellisten julkaisukäytänteiden, kuten avoimen saatavuuden, kehittäminen, mutta toistaiseksi tämä on jäänyt suurimmaksi osaksi kaupallisten kustannustalojen haltuun. (Longva et al. 2017.) Vertaisarviointi on säilynyt pitkälti muuttumattomana ja selvästi erillään itse julkaistavasta lopputuotteesta. Tällä hetkellä vallitseva käytäntö on, että lehti käsittelee vertaisarviointiprosessin täysin suljetuin kansin.Tässä prosessissa vain julkaistu artikkeli nousee lopputuotteena pintaan, mikäli käsikirjoitus hyväksytään.Vertaisarviointi on käsitetty lähinnä aineiston tuotanto- ja valikoitumisprosessina, eikä vertaisarvioprosessista itsestään jää minkäänlaista jälkeä.

Tieteellinen julkaisujärjestelmä on vuosisatojen ajan perustunut paperille painettuihin lehtiin ja kirjoihin, mikä on pitkään ollut ainoa mahdollinen tiedonjakelun tapa.Tämä ei kuitenkaan enää nykyisin ole itsestään selvää tai välttämätöntä. (Bartling \& Friesike
20।4, 7.) Julkaisemiseen liittyvät muutokset ja avoimen tieteen eetos suuntaavat väistämättä myös vertaisarviointia koskevia käytäntöjä. Tutkimusprosessien avaaminen liittyy keskeisesti avoimeen vertaisarviointiin, jonka mahdollisuuksista ei kuitenkaan vielä ole olemassa juurikaan tietoa.Vertaisarviointia pidetään yleisesti tutkimuksen laadun takeena, mutta vaikuttavatko muuttuvat käytänteet tähän ihanteeseen? Vertaisarvioinnin keskeinen asema tiedemaailmassa näkyy yliopistojen rekrytointiprosesseissa, kilpaillussa tutkimusrahoituksessa sekä julkaisemisen referee-järjestelmässä, jonka tarkastelemiseen tämä raportti keskittyy.

Jotta avoimen vertaisarvioinnin vahvuuksia ja heikkouksia voidaan punnita, liikkeelle täytyy lähteä perinteisen vertaisarvioinnin määrittelystä.Walker ja Rocha da Silva (20I5) määrittelevät perinteisen vertaisarvioprosessin seuraavilla kriteereillä:

- Arvioi käsikirjoituksen soveltuvuutta julkaistavaksi, antaa kirjoittajalle palautetta, pyrkii käsikirjoituksen laadun parantamiseen

- Formaalit käytännöt ja arviointikriteerit

- Ajankohta: ennen julkaisemista

- Selektiivinen prosessi

- Arvioi käsikirjoitusta uutuusarvon mukaan (merkitys tieteenalalle, kiinnostavuus laajemmalle lukijakunnalle)

- Tekijöinä toimittajien valitsemat anonyymit arvioijat, jotka tekevät arvion riippumatta toisista arvioijista sekä kirjoittajista

- Prosessi paättyy toimittajan / toimittajien julkaisupäätökseen

Anonyymiys, selektiivisyys ja läpinäkymättömyys määrittävät perinteistä vertaisarvioprosessia (Schmidt et al. 2018). Yleisimpänä vertaisarvioinnin tapana on pidetty puoliavointa arviointia (single-blind review), jossa tekijän identiteetti paljastetaan arvioijalle, mutta arvioijan identiteetti säilyy anonyyminä. Tuplasokkoarvioinnissa sekä kirjoittajan että arvioijan identiteetti salataan, ja se on yleisempi humanistisilla aloilla ja yhteiskuntatieteissä kuin luonnontieteiden, teknologian, insinööritieteiden ja lääketieteen aloilla.Tutkimusten mukaan sitä myös kannatetaan eniten. (Ks. Ross-Hellauer 2017, 8; Jubb 2016, 16.)

Selektiivisyydellä viitataan kutsumenettelyyn eli siihen, että toimittajat kutsuvat ja valitsevat vertaisarvioijat. Läpinäkymättömyys taas viittaa siihen, että perinteinen arvioprosessi mahdollistaa lukuisat "mustat laatikot", joiden turvin erilaisia väärinym- 
märryksiä, mutta myös väärinkäytöksiä voi päästä tapahtumaan. Tästä kirjoittajalle näkymättömän prosessin tieteellisyyden ja puolueettomuuden varmistamisesta tulee pitkälti toimittajan moraalisen vastuun kysymys (ks. Kovanen \& Saarelma 2002, 286).

Edellä esitetty perinteisen vertaisarvioprosessin kuvaus tekee näkyväksi vallitsevan kaavan prosessin alusta loppuun asti. Avoin vertaisarviointi voi merkitä muutoksia yhdessä tai useammassa edellä kuvatun prosessin kohdassa. Kun perinteisen vertaisarvion heikkouksia tai toimimattomuutta punnitaan, esiin on noussut seuraavanlaisia epäeettisiä käytäntöjä tai läpinäkyvyyteen liittyviä ongelmakohtia:

Väärinkäytökset. Tutkimustulosten julkistamisprosessin perusta on tinkimätön pyrkimys oikeudenmukaisuuteen. Vertaisarviointiprosessi perustuu luottamukseen, mutta vertaisarvioijat eivät aina tuo esiin omaa esteellisyyttään tai he voivat käyttää luottamuksellista tietoa omien etujensa ajamiseksi, tuottaa epäreilun arvion tai viivyttää arviota ja siten saada etumatkaa omalle tutkimukselleen.Vielä julkistamattoman tiedon äärelle pääseminen mahdollistaa väärinkäytökset. Nämä väärinkäytökset ovat mahdollisia juuri prosessin läpinäkymättömyyden vuoksi. Kilpailun kiihtyessä myös paine erilaisille väärinkäytöksille voi kasvaa. Julkaistuihin “lopputuotteisiin” keskittyminen jättää näkymättömiin koko julkaisua edeltäneen prosessin ja antaa väärinkäytöksille myös lisää tilaa.Vertaisarvioinnin puutteet tuottavat epäoikeudenmukaisuuden kokemuksia, joita puutteet kommunikaatiossa eivät ainakaan paranna.Vertaisarvioijia on hyvä muistuttaa heitä koskevista eettisistä säännöistä: vertaisarvioijat eivät saa hyödyntää omissa tutkimuksissaan vertaisarvioinnissa saamaansa tietoa, etenkään jos se auttaa heitä parantamaan kilpailuasemiaan. Erityisesti tästä on muistutettava arvioitsijoita, jotka tutkivat samaa aihetta kuin arvioitavan artikkelin kirjoittaja(t). (Ks. Kovanen \& Saarelma 2002, 290.)

Epäluotettavuus. Vertaisarvioprosessin merkitys tieteellisen laadun takaajana on myös kyseenalaistettu monissa tutkimuksissa. Lausuntojen subjektiivisuudesta kertoo jo se, että lausunnot ovat usein keskenään ristiriitaisia. (Ks. Binswanger 20I4, 56-57.) Arvioijat arvioivat suosiollisemmin tekstejä, jotka ovat linjassa heidän oman työnsä kanssa kuin niitä, jotka ovat sen kanssa ristiriidassa. Todisteita vertaisarvioinnin toimivuudesta ei ole, eikä myöskään sitä ole pystytty todentamaan, ovatko havaitut puutteet harvinaisia poikkeuksia vai vain jäävuoden huippu (Ware 2008).

Erilaiset vinoumat.Vertaisarviointia koskeva puhe on tunnepitoista ja usein nimenomaan negatiivista. Akateemisen statuksen ja hierarkian merkitys voi korostua vertaisarvioprosessissa, ja vertaisarviointi on myös vallankäyttöä.Vinoumat voivat liittyä myös sukupuoleen, rotuun, kieleen, kansallisuuteen tai tutkimusalaan. Tästä syystä tärkeää on monimuotoisuuden vaaliminen sekä useiden toisiaan täydentävien vertaisarvioijien käyttäminen (eri urakehityksen vaiheet, sukupuoli, maantieteellinen diversiteetti (Görögh et al. 2017,47). Historiallisesti anonyymius on alun perin liittynyt naisten, ei-englanninkielisten ja vähemmän arvostetuissa instituutioissa työskentelevien suojaamiseksi (Ross-Hellauer 2017,8). On havaittu, että puoliavoimessa arvioinnissa (single-blind), jossa arvioija tietää kirjoittajan henkilöllisyyden, saatetaan suosia tunnettujen instituutioiden etabloituneita tutkijoita. Myös miesten artikkeleita on voitu arvioida suopeammin kuin naisten. Tälöin tuplasokkoarviointi voidaan nähdä tervetulleena vaihtoehtona. (Le Goues at al. 2018.) Kuitenkin myös tuplasokkoarvioinnissa on omat kompastuskivensä. Etenkin pienillä kielialueilla kirjoittajan identifiointi on helpompaa, jolloin tuplasokkoarvio tarjoaa lähinnä vain illuusion anonyymiydestä.

Vertaisarvioijan tekemän työn näkymättömyys. Juuri läpinäkymättömyys mahdollistaa vertaisarvioijien vastuuttomuuden. Vertaisarvioprosessin kulkuun liittyvien hankaluuksien ohella yksi suurimmista ongelmista on sopivien vertaisarvioijien löytyminen.Vertaisarvioijan työ jää näkymättömäksi, vaikka se laskettaisiinkin tieteelliseksi meriitiksi.Vertaisarvioijia voivat motivoida hyvinkin erilaiset tekijät sen mukaan, kuinka oleelliseksi osaksi hän kokee yhteisön ja vastavuoroisten palvelusten merkityksen työlleen. Etabloituneet tutkijat kokevat usein vertaisarvioinnin osana työtään, nuoremmat tutkijat sen sijaan hakevat tunnustusta myös omalle ammattitaidolleen. Myös käsikirjoituksen aiheen yhteensopivuus arvioijan omiin sen hetkisiin tutkimusintresseihin lisää kiinnostusta suostua arvioijaksi.Vertaisarvioija punnitsee tarkoin vertaisarvioijaksi ryhtymisen hyötyjä suhteessa menetettyyn aikaan. Monet, usein jo tunnustetut tiedeyhteisön jäsenet, kokevat arvioinnin velvollisuutenaan sekä osana työtään ja osallisuuttaan akateemisesta yhteisöstä. (Zaharie \& Osoian 2015.) Usein saattaa unohtua myös se, että laadunvarmennus vertaisarvioinnissa koskee varsinaisen arvioinnin kohteena olevien käsikirjoitusten laadun ohella myös vertaisarviolausuntojen laatua (Görögh 2017,24). Myös vertaisarvioijalle on mahdollista antaa palautetta hänen kirjoittamastaan lausunnosta.

Vertaisarvioprosessin hitaus. Vallitsevien vertaisarviointikäytäntöjen ongelmallisuus korostuu yhä kasvavan tehokkuuden ja nopeuden vaatimuksen myötä. Prosessin hitaus liittyy olennaisesti moniin edellä mainittuihin ongelmiin. Ennen kaikkea prosessia hidastaa sopivien vertaisarvioijien löytyminen, ristiriitaiset lausunnot sekä 
käsikirjoituksen mahdollisesta hylkäämisestä koituva moninkertainen työ. Tarvitaan yhä enemmän ja enemmän asiantuntijoita arvioimaan yhä kasvavia määrïa julkaistavaksi tarkoitettuja käsikirjoituksia. Prosessi hidastuu, jos sopivia vertaisarvioitsijoita ei löydy. Perinteinen malli ei välttämättä enää ole tutkimuksen edistämisen kannalta optimaalinen.

Myös monitieteisyyden haasteet ja mahdollisuudet ovat tärkeä osa vertaisarviointiprosessia (Casnici et al. 20I7). Monitieteisiä tutkimuksia arvioi usein suurempi joukko vertaisarvioijia, jolloin kirjoittajat saattavat kokea joutuvansa kohtuuttoman kriittisen arvioinnin kohteeksi. Tutkijat saattavat pelätä myös sitä, että yksittäistä tieteenalaa edustavat arvioijat eivät tavoita monitieteisten löydösten merkittävyyttä. (Jubb 20 I6, I5.)

Vertaisarvioinnin tavoitteena pidetään yleisesti käsikirjoituksen laadun parantamista. Tämän ohella tavoitteena voi olla ottaa kantaa työn omaperäisyyteen ja uutuusarvoon tai siihen, onko teksti sopiva kyseiseen julkaisuun. Koska vertaisarvioinnin tavoitteista ei ole yksimielisyyttä, myöskään siitä, kuinka hyvin se käytännössä täyttää tehtävänsä, ei voi olla yksimielisyyttä (Jubb 2016, I3-I4). Jos referee-järjestelmä toimii huonosti, voidaan hyviä artikkeleita hylätä ja huonoja julkaista. Edellisessä tapauksessa vääryyden kokee tutkija, jälkimmäisessä tiedeyhteisö. (Kovanen \& Saarelma 2002,278 .) Reaktiona näihin vinoumiin ja epäreiluun tai vanhakantaiseen arviointiprosessiin vaihtoehtoisia toimintatapoja on haettu avoimesta vertaisarvioinnista sen eri muodoissa.

\section{Vertaisarvioinnin uudet muodot ja muutokset}

Tiedelehtien joukko ja myös niissä julkaistujen artikkeleiden määrä on kasvanut jatkuvasti (Bornmann \& Mutz 20I5). Tämän myötä paine uudistaa ja muokata vertaisarviointiprosesseja on myös lisääntynyt. Tässä osiossa esitämme joitakin keskeisiä vertaisarviointiin liittyviä uusia käytäntöjä, jotka eivät liity ainoastaan prosessin avaamiseen vaan kokonaisvaltaisemmin siihen miten, milloin ja kuka vertaisarvioinnin voi suorittaa.

Walker ja Rocha da Silva (20I5) nostavat esiin kaksi innovaatiota, jotka ovat heidän mukaansa vaikuttaneet eniten tiedejulkaisemisen kentällä. Ensimmäinen on erilaisten digitaalisten julkaisuarkistojen nopea kasvu ja toinen on ei-selektiivinen arviointiprosessi. Itse julkaisemisen käsite muuttuu, kun se irrottautuu perinteisestä muodostaan
(= tutkimusartikkeli tiedelehdessä) (Görögh et al. 20I7, I I-I2). On syntynyt alustoja, kuten ArXiv ja Zenodo, joilla voi avoimesti ja ilmaiseksi "julkaista” (make available) dokumentteja, dataa ja hypoteeseja. Lehdet kuitenkin ovat edelleen säilyttäneet asemansa portinvartijana sille toiminnalle, mikä ymmärretään julkaisemisena. PLoS One-lehden yleistämässä "ei-selektiivisessä arvioinnissa" tehdään ero arvioinnin (review) ja arvottamisen (evaluation) välillä: uutuusarvon sijaan painotetaan tieteellistä laatua. Käsikirjoituksia ei enää hylätä uutuusarvon puutteen vuoksi tai siksi, että ne haastavat valtavirran tiedekäsitystä. Käytännössä tämä on tarkoittanut "objektiivista arviointia", jossa ainoat hyväksyttävät syyt paperin hylkäämiselle ovat puutteellinen raportointi tai virhe. Prosessissa ei oteta kantaa artikkelien tieteelliseen merkittävyyteen, tavoitteena on todella vain varmistaa, että julkaistava teksti on metodeiltaan ja muodoltaan tieteellisten käytäntöjen mukainen. Ei-selektiivisessä mallissa julkaisumääriä ei pyritä keinotekoisesti rajoittamaan. Tällä menettelyllä vertaisarvioinnin rooli julkaisuprosessin portinvartijana heikentyy, mutta kuitenkin säilyttää roolinsa laadunvarmentajana. Tämä on tarjonnut parempia mahdollisuuksia mm. negatiivisten tulosten julkaisemiseen. (Ilva \& Lilja 20I4, I4.) Kovanen \& Saarelma (2002, 282) visioivat 2000-luvun alussa sellaista julkaisemisen tulevaisuutta, jossa yhteen suureen verkkojulkaisuun koottuna kaikki hyvän tieteellisen tavan mukaan suoritettu tutkimus voidaan julkaista. Tällöin myös referee-järjestelmä uudistuisi: enää ei hyväksyttäisi ja hylättäisi, vaan tutkimus pisteytettäisiin sen merkityksen mukaan. Merkittävyyden pisteyttäminen voisi kuitenkin osoittautua vaikeaksi tehtäväksi.

Suuri osa käsikirjoituksista saa lehdiltä kielteisen julkaisupäätöksen. Mitä tehdä ei-julkaistujen käsikirjoitusten arvioiden kanssa? Nopeutta peräänkuulutetaan, jotta vertaisarviointiin ei menisi liian paljon aikaa riippumatta siitä, päättääkö lehti julkaista käsikirjoituksen vai ei. Jotta vertaisarvioprosessiin kuluva työ ja aika ei valuisi kielteisen päätöksen mukana täysin hukkaan, on uusia ideoita vertaisarvioinnin toteuttamiseen kokeiltu. Tiedejulkaisemisen kentällä on luotu esimerkiksi itsenäisiä vertaisarviointia suorittavia alustoja, kuten Rubriq ja Editage. "Kannettavassa/ siirrettävässä vertaisarvioinnissa" (portable review) vertaisarviointi on artikkelikohtaista ja lehdestä riippumatonta. Isoilla julkaisijoilla voi olla sekä selektiivistä että ei-selektiivistä vertaisarviointia käyttäviä lehtiä, jolloin käsikirjoitus vertaisarvioineen voi kulkeutua julkaistavaksi toisessa lehdessä tultuaan hylätyksi toisessa, samoilla arvioilla. Muun muassa Elsevierin Heliyon-lehti toimii tällaisen prosessin alatasolla, johon moni julkaisijan selektiivistä vertaisarviointia harrastava lehti lähettää materiaalit kirjoittajien siihen suostuessa. Kirjoittaja voi myös tarjota tekstiään useisiinkin julkaisukanaviin ennen sopivan löytymistä, ja vertaisarviolausunnot kul- 
kevat mukana. Peerage of Science on irrottanut vertaisarvioinnin lehtien yhteydestä omaksi itsenäiseksi kokonaisuudekseen. Monet lehdet arvostavat kuitenkin edelleen vertaisarvioitsijoita, jotka tuntevat lehden linjan ja ovat kiinteästi yhteydessä sen konteksteihin (Jubb 2016, 17-19).

"Julkaisun jälkeisessä vertaisarvioinnissa" (post publication peer review) vertaisarvio suoritetaan vasta sen jälkeen, kun käsikirjoituksen ensimmäinen versio on jo julkaistu. Näin toimitaan esimerkiksi FI000 Research ja Science Open -alustoilla. Tällainen käytäntö muuttaa radikaalisti esioletusta siitä, että laaduntarkkailu edeltäisi aina julkaisua. Toistaiseksi käytäntö ei kuitenkaan ole yleistynyt eikä julkaisun jälkeinen arviointi suinkaan ole korvaamassa perinteistä vertaisarviointia vaan ennemminkin täydentää sitä. (Jubb 2016, 17-18.)

Perinteisen vertaisarvion läpikäynyttä paperia voidaan myös kommentoida esimerkiksi sosiaalisessa mediassa tai kustantajan sivuilla. Esimerkiksi PubPeer on sivusto, jossa tutkijat voivat kommentoida julkaistuja artikkeleita. Tällöin voidaan puhua "yhteisöllisestä arvioinnista" (public/community review). Tieteellisten julkaisujen vertaisarvioijaan viitataan usein referee-lukijana, kun halutaan korostaa sitä, että kyseessä ei ole vertaisten välinen toiminta vaan toimintaan voi sisältyä hierarkiaa (referee =tuomita). Uusissa julkaisumalleissa "vertaisen" käsite alkaa saavuttaa alkuperäistä merkitystään enemmän vertaisten kuin vain pienen asiantuntijaeliitin arvioitavana olemisesta (Görögh et al. 2017,43).

Uudet teknologiat ovat muuttaneet tieteellisen julkaisemisen kenttää ja mahdollistaneet julkaisumäärien rajun nousun. Uusien vaihtoehtoisten arviointityökalujen- ja metodien ilmaantuminen järjestää uudelleen julkaisusysteemiä ja samalla myös väistämättä määrittelee sitä uudelleen.Vaihtoehtoiset käytännöt eivät kuitenkaan kyseenalaista vertaisarvioinnin merkitystä ja roolia vaan arvioivat uudelleen nykyistä järjestelmää ja sen työnkulkua. (Görögh et al. 20 I7, I I, 4I.)

\section{Avoimen vertaisarvioinnin tehtävät ja tavoitteet}

Tieteessä avoimuuden nykytila on muovautunut ja jatkaa muovautumistaan monen vahvan intressin seurauksena.Vielä ei ole juuri tutkittu, millaisia asetelmia nykyinen tieteen avoimuus luo vertaisarviokäytäntöjen kannalta. Avoin vertaisarviointi onkin osa laajempaa avoimen julkaisemisen ja avoimen tieteen politiikkaa. Avoin julkaise- minen on 2000-luvun alusta lähtien edistynyt hitaasti mutta varmasti. Maksumuurit murenevat päivä päivältä, mutta julkaistun aineiston avoimuuden asteen kasvu ei ole tuonut mukanaan merkittävästi avoimempia käytäntöjä itse tiedelehtien aineistojen kokoamiseen, vaikka tekniset edellytykset ovat olemassa. Avoin julkaiseminen ja avoin vertaisarviointi eivät käytäntöinä ole toisistaan riippuvaisia, mutta toistaiseksi suurin osa avointa vertaisarviointia harjoittavista lehdistä myös julkaisee avoimesti (Wang \& Tahamtan 2017).

Avoimuus käsitteenä on monisyinen eikä sille ole olemassa yhtä selkeää määritelmää. 'Yliopistoissa linjataan yhä useammin, että kaikkien tutkimusprosessin aikaisten tuotosten avaaminen on osa akateemista ansioitumista. Mitä tämä tarkoittaa vertaisarvioinnin kannalta? Tieteellisen tiedon ja tietoaineistojen avoimuuteen liittyy yleviäkin arvoja ja ihanteita, kuten tasa-arvo ja vapaus. Keskeisiä periaatteita ovat myös saatavuus, näkyvyys ja vaikuttavuus. Kansallisella tasolla eri yliopistoissa vallitsevat erilaiset avoimen tutkimuksen politiikat, joihin voi kuulua tutkimusprosessien avaamisen, teknologian ja tieteen kehityksen sekä (yhteiskunnallisen) vaikuttavuuden kaltaisia tekijöitä.

Muiden avoimen tieteen alueiden ohella avoin vertaisarviointi on ajankohtainen ja yhä kasvava aihe, jota tutkitaan ja josta kirjoitetaan yhä enemmän (Ross-Hellauer 2017, 3; Görögh et al. 2017). Avoimuuden innovaatioissa ei ole kyse nykyisten systeemien romuttamisesta vaan uudelleen arvioinnista. Uudelleenarviointi koskee lehtien ja vertaisarvioinnin välistä muuttuvaa suhdetta. Vertaisarviointi itsessään on välttämätön, mutta sen käytännöistä ja malleista voidaan olla eri mieltä (Ross-Hellauer 20I7, 3; Jubb 20I6).

Avoimen vertaisarvioinnin tavoitteena on tieteellisen kommunikaation ja julkaisukäytäntöjen parantaminen. Tähtäimessä on selkeyttää vertaisarvioijien, kirjoittajien, tiedelehtien ja lukijoiden eli jokaisen julkaisuprosessiin osallistuvan toimijan roolia sekä myös kyseenalaistaa ajatus suljetun vertaisarvioinnin paremmuudesta. Huomioon on kuitenkin otettava, että jo avoimen vertaisarvioinnin käsite itsessään on monitahoinen ja vaatii tarkennusta. Keskeistä on, että avointa vertaisarviointia ei voi lähestyä yhtenä staattisena, historiattomana kokonaisuutena (Tennant et al. 2017). Vertaisarviointi on käsite, ei metodi, ja sellaisenaan monikäyttöinen (Görögh et al.

I Avoimen tieteen teemoihin lasketaan avoimen vertaisarvioinnin ohella avoin data, open access (tutkimustulosten avoin saatavuus), avoin lähdekoodi, avoin metodologia sekä avoimet koulutusresurssit. Avoimessa tieteessä ei ole kyse siis vain vapaasta saatavuudesta vaan avoimuus sisältää myös prosessia tukevan metodologian sekä sen, miten tetoa arvotetaan, jaetaan ja kaytetaan uudelleen. (Gorogh et. al. 2017 , I0-1I.) Lisaa avoimen tieteen reunaehdois-
ta ja tieteellisen tiedontuotannon muutoksista ks. esim. Opening Science. The Evolving Guide on How the Internet Is Changing Research, Collaboration and Scholarly Publishing, https://doi.org// O. I 007/978-3-319-00026-8. 
$2017,22)$. Ross-Hellauer $(2017, \mathrm{II})$ ehdottaa, että avoin vertaisarviointi ymmärrettäisiin monia, osin päällekkäisiäkin vertaisarviomalleja mahdollistavana sateenvarjokäsitteenä.Avoimella vertaisarvioinnilla voidaan viitata järjestelmään, jossa sekä kirjoittajan että vertaisarvioijan identiteetit paljastetaan. Sillä voidaan viitata myös malliin, jossa anonyymiys sälyy, mutta arvioijien lausunnot julkaistaan. Edelleen sillä voidaan viitata tilanteeseen, jossa arvioijina voivat toimia muutkin kuin alan asiantuntijat. Yhteistä näillä kaikille näkökulmille on se, että ne toimivat linjassa avoimen tieteen eetoksen kanssa ja pyrkivät toteuttamaan läpinäkyvämpää, vastuullisempaa ja joustavampaa toimintatapaa kuin perinteinen vertaisarviomalli (Ross-Hellauer 20I7, II).

Avoin vertaisarviointi sisältää yleisimmin joko yhden tai useamman käytännöistä, jotka on lueteltu taulukossa I (ks. esim. Görögh et al. 2017 ja Ross-Hellauer 2017):

\begin{tabular}{|l|l|}
\hline Avoimet lausunnot & Vertaisarviolausunnot julkaistaan artikkelin rinnalla. \\
\hline Avoimet identiteetit & Kirjoittajan ja vertaisarvioijan henkilöllisyyksiä ei salata. \\
\hline Avoin osallistuminen & $\begin{array}{l}\text { Laajemman yhteisön (kuin vain kutsuttujen } \\
\text { vertaisarvioijien) on mahdollista osallistua } \\
\text { vertaisarvioprosessiin. }\end{array}$ \\
\hline Avoin vuorovaikutus & $\begin{array}{l}\text { Vertaisarviomenetelmä, joka sallii kirjoittajan ja } \\
\text { vertaisarvioijan tai vertaisarvioijien välisen kommunikaation } \\
\text { ja rohkaisee siihen. }\end{array}$ \\
\hline
\end{tabular}

\section{Taulukko I - Avoimen vertaisarvioinnin pääkäytännöt}

Tällainen avoimen vertaisarvioinnin määritelmä sallii asteittaisen siirtymisen kohti avoimuutta, jolloin avoimuuteen rohkaistaan, mutta täyttä avoimuutta ei edellytetä.

Avoimen vertaisarvioinnin avulla yritetään ratkaista julkaisuprosessin läpinäkyvyyteen liittyviä ongelmia, sillä oletuksella, että läpinäkyvyys parantaa koko vertaisarvioprosessin laatua. Erilaisten vinoutumien väheneminen ja toimijoiden lisääntynyt vastuullisuus voivat johtaa prosessiin, jossa arviot ovat entistä rakentavampia, ja jossa myös arvioijat saavat tunnustusta työstään.

Läpinäkyvyys liittyy kaikkiin avoimen vertaisarvioprosessin toimijoihin. Keskeisessä roolissa sekä suljetussa että avoimissa malleissa ovat vapaaehtoiset vertaisarvioijat.
He ovat useimmiten tutkijoita, joiden kirjoittamiin arvioihin lehtien toimituskunnat pitkälti nojaavat tehdessään lopullisia julkaisupäätöksiä.Tieteellisiä artikkeleja ja kirjoja kirjoittavat haluavat, että heidän käsikirjoituksensa saa alansa asiantuntevimmat arviot. Tiedelehdelle avoin vertaisarviointi luo mahdollisuuden näyttää lukijoille, että lehti tosiaankin suorittaa perusteellisen vertaisarvion. Tämä poistaa kaikki epäluulot lehden linjasta ja laadusta. Avoimessa prosessissa myös lukijat saavat halutessaan enemmän läpinäkyvyyttä kiinnostavan artikkelin tueksi sillä he pääsevät näkemään, miten alan asiantuntijat ovat kommentoineet tutkimuksen heikkouksia ja vahvuuksia. Tärkeää on tunnistaa, että erilaiset prosessit vastaavat erilaisiin tarpeisiin. Tunnettujen instituutioiden ja kirjoittajien intressit ovat erilaiset kuin aloittelevien tutkijoiden. Tieteentekijät etsivät uusinta, erikoistunutta tietoa, kun taas toiset haluavat seurata myös oman alansa ulkopuolista tutkimusta. (Walker \& Rocha da Silva 20I5, I5.)

Avoin vertaisarviolausunto voi toimia aloittelevalle tutkijalle arvokkaana oppaana mm. siinä käytetyn äänensävyn, arvion pituuden ja kritiikin formuloinnin tasoilla (Ross-Hellauer 2017, 9).Vertaisarvioitsijoiden koulutuksen mahdollisuus nousee esiin aika ajoin. Vertaisarviointi sopisi jossain muodossa tutkijakoulujen ohjelmaan kuten tieteellinen kirjoittaminenkin (Raivio 2006). Täysin suljetussa vertaisarvioinnissa tieteen kehityksen kannalta arvokasta materiaalia menee hukkaan. Avoin vertaisarviointi mahdollistaa paremman ymmärryksen siitä, miten tieteellinen tieto muodostuu.

Täysin avoin osallistuminen tarkoittaa sitä, että kuka tahansa voi arvioida julkaistavaksi tarjottua tekstiä. Parhaimmillaan tämä keventää toimituskunnan taakkaa sopivien vertaisarvioijien löytämiseksi. Tämän lisäksi se mahdollistaa useamman näkökulman artikkeliin kuin vain muutaman kutsutun. Vertaisarvioijat voivat myös olla liian kriittisiä ladatessaan epärealistisia odotuksia käsikirjoitukselle, jolloin toimittajan rooli kasvaa.

Avoimuuden monista mahdollisista asteista huolimatta vain muutamat lehdet ja julkaisijat ovat toistaiseksi lisänneet avoimuutta, mutta määrä kasvaa koko ajan (Wang \& Tahamtan 2017). Niistä merkittävinä esimerkkeinä ovat yli 70 BioMed Central -lehteä ja FI000 Research-lehti, joissa vertaisarviot ja kirjoittajien mahdolliset vastaukset niihin ovat kaikkien artikkeleiden ohella nähtävissä. Myös EMBO Journalissa vertaisarviolausunnot julkaistaan artikkelin rinnalla, ja arvioitsijat myös kommentoivat toistensa arvioita. Arvioijien nimiä ei kuitenkaan julkaista. Näyttää siltä, että käytäntö arvioiden julkaisemisessa on leviämässä myös laajemmalle varsinkin luonnontieteissä, joissa kasvava määrä lehtiä ja julkaisijoita on äskettäin allekirjoittanut yhteisen julkilausuman (http://asapbio.org/letter). 
Avoimen vertaisarvioinnin nouseviin trendeihin kuuluu interaktiivisuus, jossa toimittajat, arvioijat ja kirjoittajat työskentelevät yhdessä. Myös formaali, julkaisemisen jälkeinen arviointi sekä epämuodolliset lukijakommentaarit kasvattavat suosiotaan. (Walker \& Rocha da Silva 2015, 14; ks. myös Jubb 2016, 16.) Esimerkiksi eLife hyödyntää toimittajan online-konsultaatiota, jossa vertaisarvioijat näkevät toistensa lausunnot ja identiteetit.Arvioijat keskustelevat lausunnoistaan toistensa ja lehden toimittajien kanssa saavuttaakseen yhteisen näkökannan. Prosessi hyödyttää sekä arvioijia, jotka saavat kokemusta keskustelusta, että kirjoittajaa, joka saa koherentin, dialogiin perustuvan palautteen. (Jubb 2016, 16.; Schmidt et al. 2018,4.) Joissain tapauksissa epämuodollinen keskustelu on jopa johtanut tieteelliseen kontribuutioon (Walker \& Rocha da Silva 2015, 14).Avoimuuden ja konsensushenkisyyden kääntöpuolena voi kuitenkin olla vaikeus esittää kritiikkiä: johtaako keskustelu konsensukseen vai ristiriitoihin?

Avoimuuden nimissä myös vertaisarvioitsijoiden meritoitumiseen on kiinnitetty huomiota.Vertaisarvioija suorittaa tehtävän useimmiten ilman korvausta. Julkaisumäärien noustessa myös vertaisarvioinnin muodostama taakka tiedeyhteisössä kasvaa. Niin kauan kuin arvioitsijoiden työ on suurimmilta osin näkymätöntä, muut työt ajavat helposti sen ohi. Uudet aloitteet kuten https://publons.com paikkaavat tätä tilannetta jonkin verran. Siellä suoritettu niin sanottu suljettu vertaisarvio rekisteröidään tutkijan luomalle henkilökohtaiselle tilille. Näiden meriittien hyödyntäminen riippuu kuitenkin sopimuksesta julkaisijan kanssa. Avoin vertaisarviointi, jossa edes nimet julkaistaan artikkelin yhteydessä, mahdollistaa meriittien kokoamisen mihin vain. Myös vertaisarvioinnille voidaan antaa erilaisia painoarvoja, kuten esim. Philicassa, jossa menestyneiden arvioijien antamat lausunnot saavat enemmän painoarvoa (Görögh et al. 2017, 30).

Avoimesti saatavilla olevien julkaisujen ja preprint-julkaisukanavien suosiminen suuntaa väistämättä myös vertaisarviointia koskevia käytäntöjä.Tutkimusprosessien avaaminen liittyy keskeisesti avoimeen vertaisarviointiin, mutta tietoa ja ohjeistusta siitä on toistaiseksi olemassa vain vähän, huolimatta sen keskeisyydestä tieteenteon arjessa. Julkaisemisen ja laajemmin tutkimuksen avoimuudesta ei ole vielä systemaattista keskustelua, ja sen vaikutusten hahmottelu etenkin vertaisarvioprosesseihin on vielä pitkälti irrallista.

\section{Avoimen vertaisarvioinnin haasteita}

Edellä on lyhyesti esitelty, mitä julkaisemiseen liittyviä ongelmia avoin vertaisarviointi yrittää ratkaista ja miten. Avoin vertaisarviointi tarjoaa keinoja läpinäkyvyyden lisäämiseksi, mutta se ei pysty estämään kaikkia tieteentekoon ja julkaisemiseen liittyviä pulmia tai väärinkäytöksiä. Perinteinen vertaisarvioprosessi puolustaa yhä paikkaansa tieteellisen julkaisemisen ekosysteemissä (Walker \& Rocha da Silva 2015, 6, I5).

On kysyttävä myös, kuka hyötyy avoimesta vertaisarvioinnista eniten ja minkälaisia vinoumia tai hierarkioita sen käytännöt voivat tuottaa (Schmidt et al. 2018,5). Hitaudesta ja nopeudesta puhuttaessa prosessin nopeuttamisen taustamotiivina voi olla myös ulkoa ohjattu tehostaminen. Juuri menestymisen edellyttämä nopeus saattaa houkutella vertaisarvioijaa eettisesti arveluttaviin keinoihin, kuten toisen tekemän työn hidastamiseen.

Vertaisarvioprosessiin kuuluvat ihanteet, kuten luottamus ja arvostus. Kuitenkin myös inhimillisen toiminnan realiteetit on otettava huomioon, kuten Hallamaa (2002) huomauttaa: "Tieteen tekeminen ei ole sen ihanteellisempaa kuin mikään muukaan inhimillinen toiminta, vaan myös tutkijat voivat keinoja kaihtamatta pyrkiä saavuttamaan mainetta ja kunniaa, kuuluisuutta, aseman, valtaa tai taloudellisia etuja." Hallamaa kysyy, onko ylipäätään mahdollista määritellä yleispäteviä tutkimuseettisiä normeja. Myös tieteen kansainvälistyminen mutkistaa tilannetta, sillä se, mikä yhtälllä hyväksytään, voi toisaalla olla kiellettyä. (Hallamaa 2002.) "Puhdasta vertaisarvioprosessia" ilman vinoumia ei voi saavuttaa. Tämä ei kuitenkaan tarkoita sitä, ettei läpinäkyvyyden lisäämiseksi olisi syytä ponnistella.

Suhtautuminen avoimeen vertaisarviointiin on tieteenalakohtaista. Tieteenalaerojen vuoksi tutkimustuloksia erilaisten vertaisarviomallien toimivuudesta ei voida yleistää (Ross-Hellauer 2017, 8). Tutkimus on osoittanut vertaisarvioprosessien erot eri tieteenaloilla ja sen, että erot eivät tulevaisuudessa suinkaan ole katoamassa vaan eriytyminen jatkuu yhä (Walker \& Rocha da Silva 20I5). Esimerkiksi luonnontieteissä ei yleensä pyritä salaamaan kirjoittajan identiteettiä, joten jo arviointiprosessin lähtökohdat ovat hyvin erilaiset kuin vaikkapa humanistisen tutkimuksen kentällä.

Vertaisarvioijien identiteettien paljastamista puolletaan usein eettisiin seikkoihin vetoamalla: anonyymisyys mahdollistaa läpinäkymättömyyden ja siten myös erilaiset väärinkäytökset, joten prosessi on artikkelin kirjoittajan kannalta epäreilu. Samaan aikaan on kuitenkin muistettava, että julkaisupäätöksen tekee toimittaja, ei vertaisar- 
vioija.Toimittaja myös kantaa vastuun päätöksistään. Toimittaja voi myös estää suurimman osan ongelmista, joita avoin vertaisarviointi pyrkii korjaamaan - hitaus, toisen tekemän työn tulosten hyödyntäminen, vihamielisyys (Nature Neuroscience, 1999).

Tämä kertoo osaltaan toimittajien merkityksestä prosessissa ja asettaa samalla pohdittavaksi kysymyksen toimittajien vastuun mahdollisesta lisääntymisestä prosessien avaamisessa. Avoimuus pakottaa toimittajat vastuuseen päätöksistä, jotka koskevat sekä vertaisarvioijan valintaa että sitä, miten toimittajat ovat arvioita tulkinneet. Läpinäkyvyyttä voidaan lisätä myös siinä, minkälaiset periaatteet ohjaavat vertaisarvioijan valintaa:Vertaisarvioijalle annettava ohjeistus vaihtelee suuresti, joten on kiinnitettävä huomiota ohjeisiin ja siihen, kuinka ne suuntaavat arvion kirjoittamista.

Joissain lehdissä kirjoittajan annetaan ainakin osittain itse ehdottaa vertaisarvioijia tekstilleen.Tällainen apu on tervetullutta tilanteessa, jossa tutkija itse usein parhaiten tietää tutkimuskenttänsä asiantuntijat. Tutkimusten mukaan kirjoittajien itse valitsemat vertaisarvioijat kuitenkin arvioivat tekstiä myötämielisemmin kuin toimittajien valitsemat asiantuntijat, mikä on hyvä ottaa huomioon (Bornmann \& Daniel 2010). Kaikilla vertaisarvioituja artikkeleita julkaisevilla lehdillä on olemassa jonkinlaiset ohjeet, joita vertaisarvioijien toivotaan noudattavan. Harvinaisempaa on, että lehti paljastaa, minkälaisia periaatteita se noudattaa vertaisarvioitsijoita valitessaan. Joko mitään selkeää linjaa ei ole tai linjaukset ovat implisiittisiä, jolloin läpinäkyvyyden kannalta voisi olla hyödyksi avata vertaisarvioijalta vaadittavia edellytyksiä tai sitä, mitkä periaatteelliset seikat estävät vertaisarvioijana toimimisen.

On myös näyttöä siitä, että nimien paljastaminen lisäisi arviointitehtävästä kieltäytymistä (Jubb 2016, 16).Vaikeuttaako nimien paljastaminen entisestään sopivien vertaisarvioijien löytämistä, kun sekä kirjoittajan että vertaisarvioijan identiteetit alkavat saada yhä enemmän painoarvoa prosessissa? Myös vinoumat, joita tuplasokkoarvio pyrkii poistamaan, saattavat säilyä ja ainoastaan muuttaa muotoaan: toimijoiden väliset hierarkiat ja asema instituutiossa saattavat estää kriittisten kommenttien esittämisen.

\section{Kotimaiset tiedelehdet murrosvaiheessa}

\section{Vertaisarviointi ja tiedeyhteisön merkitys}

Kansainvälisissä vertaisarviointia ja avointa tiedettä koskevissa keskusteluissa on hahmoteltu mahdollisuuksia julkaisuprosessin avaamiseksi. Mitä kaikkea tämä tarkoittaa Suomen tiede- ja julkaisukentällä, sen erityisyys huomioon ottaen? Tärkeä motivaatio on edesauttaa tieteen avoimuutta ja läpinäkyvyyttä - eli edistää perinteistä tieteen tekemisen ideaalia: tiede kuuluu kaikille. Kuitenkin kyseessä on monimutkainen ja monimuotoinen ilmiö, jota luonnehtivat maantieteellisten ja tieteenalakohtaisten perinteiden ja käytänteiden erot. Myös julkaisemiseen liittyvät rahoituskuviot ja kaupalliset intressit määrittävät osaltaan vertaisarviointia koskevaa keskustelua. Kansallisen ja kansainvälisen julkaisemisen kehityskulut ja erityispiirteet onkin otettava huomioon.

Avoimen julkaisemisen ja avoimen tieteen teemat ovat tiedekustantajille ja -julkaisijoille melko tuttuja. Avoimeen julkaisemiseen likeisesti liittyvä avoin vertaisarviointi on kuitenkin toistaiseksi vähemmän keskusteltu kokonaisuus ja haastava kysymys, joka koskee laajasti koko kentän toimijoita tutkijoita myöten. Toisin kuin kansainvälisissä keskusteluissa, Suomen tiedekentällä avoin vertaisarviointi on suhteellisen tuntematon ilmiö ainakin käytäntöjen tasolla.

Tieteen historiassa arvioinnin menetelmät ovat vaihdelleet, ja vertaisarvioinnin kehittyminen keskeiseksi tieteellisen tason arviointimenetelmäksi liittyy olennaisesti tiedeyhteisön käsitteeseen. Suomalaisessa yhteiskunnassa tiedeyhteisön merkitys näkyy ennen kaikkea siinä, että tieteelliset seurat ovat olleet ja ovat yhä edelleen keskeisessä asemassa tiedeviestinnässä ja tieteen julkaisijoina. Kysymyksen jonkin väitteen, havainnon tai keksinnön tieteellisestä totuudesta ratkaisee viime kädessä tiedeyhteisö, eivät yksittäiset tutkijat. Juuri tiedeyhteisö toimii tieteellisen objektiivisuuden takaajana. Tieteen julkisuusperiaatteen mukaan tieto edellyttää tutkimustulosten julkaisemista tiedeyhteisön saavutettavaksi ja keskusteltavaksi.Tieteellisen tutkimuksen vertaisarviointi perustuu asiantuntijuuteen: laatu on sitä, mitä tiedeyhteisö pitää laadukkaana. (Ks. esim.Allardt 2002, 305; Niiniluoto 2013) Vertaisarviointia voidaan pitää loistavana osoituksena tiedeyhteisön solidaarisuudesta (Raivio 2006). Juuri tieteelliseen yhteisöön identifioituminen on keskeistä vertaisarvioprosessissa, joskin määritelmät yhteisöstä voivat vaihdella abstraktista kaikkien tutkijoiden muodostamasta yhteisöstä hyvinkin konkreettiseen käsitykseen rajatusta tutkijajoukosta (ks. Zaharie \& Osoian 20I5). 
Kansainvälisellä tasolla tieteellisten seurojen merkitys julkaisutoiminnassa on vähentynyt kaupallistumisen myötä (Lariviére, Haustein \& Mongeon 20I5), mutta Suomessa tieteellisten seurojen merkitys julkaisutoiminnassa on edelleen suuri (llva \& Lilja 20|4, 38). Tässä mielessä tieteellisten seurojen ja niiden lehtien muodostamat piirit voivat lujittaa yhteisöllisyyttä eikä niiden vaikutusta kannata aliarvioida. Kysymys tiedeyhteisön muodostumisesta liittyy ainakin välillisesti kysymykseen vertaisarvioitsijoiden motivaatiosta käyttää aikaansa sellaiseen toimintaan, joka ei ainakaan tällä hetkellä näkyvästi meritoi.

\section{Julkaisemisen muuttuminen}

Suomalaisten yliopistojen tulosta mitataan nykyään pitkälti julkaisuilla, ja julkaisujen määrään ja julkaisukanavien laatuun perustuvan valtionrahoituksen osuus on yhä nousussa. Askel kerrallaan tulosohjaus on vakiinnuttanut asemansa suomalaisessa yliopistomaailmassa (Sivula, Suominen \& Reunanen 2015, I5I-I53). Tulosohjaus eli yliopistojen tutkimuksen ja opetuksen arvioiminen esimerkiksi tutkintojen ja julkaisujen määriin perustuvilla mittareilla alkoi yleistyä uusliberalismin myötä I980-luvun loppupuolelta lähtien, mistä lähtien myös tutkimuksen välitöntä sovellusarvoa korostava innovaatiopuhe on yleistynyt. Tutkimusta ohjaa myös se, että päätöksenteko on siirtynyt yliopistojen ja tutkimuslaitosten ulkopuolelle.Valtaosa esimerkiksi EU:n tutkimusvaroista käytetään tarkoituksiin, jotka arvioidaan poliittisesti ja kaupallisesti tärkeiksi. Tutkimusyhteisön sisäiseen ohjaukseen kuuluvat vertaisarviointi ja tiedeyhteisön omat kriteerit, mutta myös ulkoinen ohjaus on alkanut saada yhä enemmän painoarvoa. (Allardt 2002.)

Hellman \& Poteri ovat tutkineet yliopiston rahoitusmallin ja julkaisujen laatuluokituksen seurauksia julkaisutoiminnalle.Akateemisen kirjankustantamisen ja tieteellisten aikakauslehtien ongelmat kärjistyvät Suomen kaltaisella pienellä markkina-alueella, ja kustantamiseen vaikuttavat tällä hetkellä Julkaisufoorumin lisäksi myös avoimen julkaisemisen vaatimus. (Hellman \& Poteri 2012, 15-16.)

Tieteellisten julkaisujen laadunarvioinnin järjestelmä JUFO eli julkaisufoorumi luotiin, koska haluttiin vahvistaa suomalaisen tutkimuksen asemaa kansainvälisessä kilpailussa. JUFO-luokittelussa otetaan huomioon sekä julkaisujen määrä että laatu, ja laadun kriteerinä pidetään nimenomaan tiedeyhteisössä suoritettua vertaisarviointia.Vertaisarvioinnin toimivuudesta ei kuitenkaan ole suoranaisia takeita, kuten kansainvälisessä keskustelussa edellä on jo tullut ilmi. Tieteellisten julkaisujen käyttö yliopistojen rahoitusperusteena on edellyttänyt sekä julkaisutiedonkeruun että julkaisujen laadunarvioinnin kehittämistä. Aiemmassa rahoitusmallissa (2013-20I4) korostettiin ulkomailla vertaisarvioitujen julkaisujen merkitystä. Kotimaiset vertaisarvioidut tutkimusartikkelit ja kirjat rinnastettiin kansainvälisillä ja kansallisilla tieteellisillä foorumeilla julkaistuihin vertaisarvioimattomiin kirjoituksiin. Vuosina 20I5-2016 julkaisuja alettiin painottaa julkaisutyypin ja Julkaisufoorumi-luokan perusteella. Malli painottaa entistä voimakkaammin vertaisarvioituja julkaisuja, joiden joukkoon lasketaan myös suomenkieliset vertaisarvioidut julkaisut. Julkaisukanavan tasoluokka määrittää julkaisun laadun ja osoittaa tiedeyhteisössä laajimmin arvostetut ja vaikuttavat julkaisukanavat. (Pölönen 20I5, 238-239.) Kriitikoiden mukaan Julkaisufoorumi on yksi uusi ohjaus- ja hallintamekanismi, joka tieteellisen laadun keinotekoisella kvantifioinnilla ei kuitenkaan palvele itse tutkimustyötä (ks. Patomäki 20I I). Joka tapauksessa Julkaisufoorumia koskeva keskustelu on tuonut esiin julkaisukulttuurien väliset erot ja julkaisutietojen kasvavan merkityksen tiedeyhteisön sisäisen meritoitumisen ja ulkoisen ohjauksen kriteerinä (Ilva \& Lilja 20I4, 2 I).

Steinberg on tutkinut julkaisutoiminnan kaupallistumisen ja englanninkielistymisen rinnakkaisia trendejä, jotka hänen mukaansa ovat pääsääntöisesti ruokkineet toisiaan. Tutkijoille englanninkielinen julkaiseminen tarjoaa laajimman mahdollisen yleisön ja todistaa kyvystä julkaista kansainvälisellä tasolla. Kustantajille englanninkielinen julkaiseminen tarjoaa globaalit markkinat. Paikkansa vakiinnuttaneet journaalit tarjoavat takeen siitä, että artikkeli on käynyt läpi perusteellisen vertaisarvioinnin. Legitimiteetti mahdollistaa sen, että kyseisen julkaisun tieteelliseen laatuun ja standardisoituun arviointiprosessiin voidaan luottaa. Steinberg kysyy, kumpi on luotettavampi akateemisen tarkkuuden vaalija: suuria voittoja tavoitteleva liikeyhtiö vai tieteellinen seura, jonka maine on suoraan riippuvainen julkaistun tutkimuksen laadusta. Steinberg kehottaakin tieteellisiä seuroja käyttämään hyödykseen statustaan akateemisen lahjomattomuuden tuomareina ja julkaisemisen arvojohtajina. (Steinberg 20I3.) Vertaisarvioinnilla on ratkaiseva merkitys julkaisujen avoimuutta ja erilaisia rahoitusmalleja pohdittaessa.

Lehtonen (20I I) on kiinnittänyt kriittistä huomiota julkaisemisessa tapahtuneisiin muutoksiin. Lehtosen mukaan kaupallistumisen takana on tiedeyhteisön (yliopistojen, tutkimuslaitosten, kirjastojen) tekemät ratkaisut. Sen sijaan, että kehitys veisi vapaan tiedon jakeluun, jakelukanavat alkavat ohjata julkaistavaa tietoa. Suuntana on, että artikkeleita aletaan suosia monografioiden sijaan. Kustannuspäätöstä ei välttämättä 
enää ohjaa laatu vaan institutionaalisten ostajien riittävä määrä. Lehtosen mielestä pisteyttämällä kustantajat ja julkaisusarjat kansainvälisten impaktimallien mukaan vahvistetaan kehitystä, joka ei perustuu tieteelliseen laatuun vaan kulttuuriseen dominanssiin. Sarjoja ja kustantajia arvotettaessa olisikin hänen mukaansa otettava huomioon niiden kustannuspolitiikan kontekstisidonnaiset ja ansaintalogiikkaan liittyvät ohjausmekanismit. (Lehtonen 20 I I, I-2.)

Kotimaisten lehtien kehitys suhteessa kansainvälisiin lehtiin on ollut hidasta avoimen julkaisemisen näkökulmasta katsottuna (Ilva \& Lilja 20I4,44). Avoimen julkaisemisen etuna pidetään muun muassa sitä, että tiedonhakua voidaan tehdä myös artikkelien sisällöstä, ei vain kuvailutiedoista, ja jos lisenssit sallivat, lehden sisältöä on mahdollista käyttää tiedon louhintaan. Avoimeen julkaisemiseen liittyvät edut vähentävät laadullisia riskejä, varsinkin jos avoimuuteen siirryttäessä kiinnitetään erityistä huomiota vertaisarvioinnin laatuun sekä artikkelien löydettävyyteen ja käytettävyyteen. (Ilva \& Lilja 20I4,46.) Julkaisemisen mittasuhteet ovat Suomessa pienet verrattuna suuriin kansainvälisiin kustannustaloihin, mutta infrastruktuuria on kuitenkin pystytty kehittämään. Open Journal Systems -julkaisujärjestelmä (OJS) mahdollistaa myös vertaisarviointiprosessin hallinnoinnin ja prosessiin liittyvän datan keräämisen. Tieteellisten seurain valtuuskunta ylläpitää journal.fi -julkaisualustaa, joka mahdollistaa asteittaisen avoimuuden lisäämisen myös vertaisarviointia koskevissa käytännöissä.

Ilvan \& Liljan $(2014,53)$ mukaan kotimaisten lehtien on pyrittävä samalle viivalle kansainvälisten julkaisujen kanssa toimintatapojen ja taustainfrastruktuurinsa puolesta. Vertaisarviointia koskeva kehitys on selkeästi menossa siihen suuntaan, että lehdet noudattavat alasta riippumatta aiempaa yhdenmukaisempia periaatteita. Tiedeyhteisön yhteistyöhön ja yhdenmukaisempiin toimintatapoihin on pyritty Tieteellisten seurain valtuuskunnan lanseeraaman vertaisarviotunnuksen myötä.Vertaisarviointitunnuksella kustantaja voi merkitä tieteellisen vertaisarvioinnin läpikäyneet artikkelit. Tämä liittyy kansainväliseen kehitykseen, jossa niin sanotut saalistavat lehdet voivat kirjoittajamaksujen toivossa päästää läpi tekstejä ilman kunnollista laadunvarmennusta (Ilva \& Lilja 20।4, I5-16). Toisaalta kuitenkin avoimen vertaisarvioinnin kehityssuuntia koskevassa kansainvälisessä keskustelussa korostetaan tieteenalakohtaisuuden merkitystä, jolloin myös tieteenalojen yhä jatkuva eriytyminen toisistaan poikkeaviin suuntiin on yhtä mahdollinen kehityskulku.

\section{Tiedelehtien rahoitus ennen ja nyt}

Suomessa on tällä hetkellä yli 300 aktiivisesti toimivaa tiedelehteä, jotka toimivat pääasiallisesti tieteellisten seurojen yhteydessä, ja jotka edustavat suurimmaksi osaksi humanistisia ja yhteiskuntatieteitä. Suurin osa lehdistä toimii pienellä budjetilla.

Vuosina 20II-20I2 kerättyjen tietojen mukaan kotimaisten lehtien osuus kaikista julkaisuista oli humanistisilla aloilla jopa $52,9 \%$, kun taas luonnontieteessä vastaava luku oli 3,8\% (Ilva \& Lilja 20|4).

Kuka kotimaisiin tiedelehtiin kirjoittaa ja kuka niitä lukee? Kotimaiset tieteelliset lehdet vastaavat hyvin moniin erilaisiin tarpeisiin: lehdet edesauttavat tieteellistä kommunikaatiota, meritoitumista ja verkostojen muodostumista, mutta ne toimivat myös opetusmateriaalina ja tieteellisen tiedon välittäjänä tiedeyhteisöjen ulkopuolelle (Ilva \& Lilja 20I4, 20, myös 25; kotimaisten lehtien tarpeellisuudesta ks. myös Hellman \& Poteri 20I2, I4). Kansalliset lehdet ovat aktiivisia toimijoita. Sen lisäksi, että ne huolehtivat vertaisarviointiprosessista ja julkaisemisesta, ne myös hankkivat ja ideoivat artikkeleita. Lehdissä on yleensä muutakin sisältöä kuin vertaisarvioituja artikkeleita. Tutkimustulosten julkaisemisen lisäksi ne osallistuvat tieteelliseen keskusteluun, välittävät tieteellistä tietoa suomalaiselle yleisölle ja toimivat organisaatiorajoja ylittävinä verkostoina. Vertaisarvioitujen artikkelien lisäksi esimerkiksi kirja-arvioilla on oma roolinsa myös tieteellisessä laadunarvioinnissa. (Ilva \& Lilja 20|4.)

Kotimaisten tiedelehtien tehtävä on siis huomattavasti laajempi kuin vain vertaisarvioitujen artikkelien julkaisualustana toimiminen eikä niitä voida arvottaa ainoastaan vertaisarvioidun materiaalin mukaan. Tämänhetkisen laatuluokituksen kääntöpuolena onkin vertaisarvioimattoman materiaalin aliarvostus, kun asiaa tarkastellaan tutkimuksen yhteiskunnallisen vaikuttavuuden sekä yliopistojen kolmannen tehtävän toteutumisen kannalta (ks. Hellman \& Poteri 2012, 17; Heinonen \& Raevaara 2012). Kotimaisilla kielillä julkaisemiselle ja yhteiskunnalliselle vuorovaikutukselle nähdään yhä edelleen olevan tarvetta.

Julkaisukentän toimintarakenne on 20I0-luvun lopulla muuttumassa, ja kotimaiset lehdet ovat joutuneet punnitsemaan omia toimintaedellytyksiään. Kotimaiset tiedelehdet ovat useimmiten jonkin tieteellisen seuran julkaisemia ja ne kamppailevat rahoituslähteiden ja toimihenkilöiden löytämisen kanssa. Toimihenkilöille ei pääsääntöisesti makseta palkkaa vaan korkeintaan pieniä palkkioita. Työtä tehdään sivutoimisesti, ja sen houkuttelevuus vähenee sitä mukaa kun akateeminen kilpailu kovenee. 
Suurin osa kotimaisista tieteellisistä lehdistä julkaistaan yhä painettuina, ja lehdet pelkäävät menettävänsä tilausmaksuja, kun toimintaa hankaloittavat jo valmiiksi jäsenkato ja vaikeus löytää seuratoimintaan sitoutuneita aktiiveja. Jos lehti on ainoa jäsenetu ja se muuttuu avoimeksi, jäsenmaksun maksamisen peruste pitää löytyä muualta. Mistä resurssit jatkossa saadaan? Tällä hetkellä lehtien rahoitus koostuu tilausmaksuista, valtionavustuksesta sekä seurojen tuesta, mutta tulevaisuuden rahoitusratkaisut ovat epävarmoja.Tieteellisten seurain valtuuskunnan ja Kansalliskirjaston yhteishanke Kotilava on etsinyt ratkaisuja avoimen tieteellisen julkaisemisen rahoitukseen ja tekniikkaan. Muutos kohti avointa julkaisemista on jo tapahtumassa, joten lehtien toimintaedellytysten turvaaminen on tärkeää. Painetuilla lehdillä on korkeat julkaisukustannukset mutta pienet budjetit, joten ne joutuvat väistämättä valikoimaan tarkkaan julkaistavaksi tarjotut käsikirjoitukset. Avoin julkaiseminen muuttaa tätä toimintamallia. Muutos painetuista sisällöistä digitaalisiksi merkitsee isoa muutosta myös julkaistavien sisältöjen rajauksen suhteen. Kun aiemmin julkaisun sivumäärä rajasi mahdollisuuksia, nyt tilanpuute ei enää määritä päätöstä ainakaan samassa mittakaavassa.Tämä tarjoaa ainakin teknisesti mahdollisuuden myös esimerkiksi vertaisarviolausuntojen julkaisemiselle.

Mitä vertaisarvioinnin hitaus ja kalleus tarkoittaa juuri kotimaisten tiedelehtien, sen kirjoittajien, arvioijien ja kustantajien kannalta? Kotimaisella kentällä vertaisarviointia koskevat ongelmat näyttäytyvät erilaisina kuin kansainvälisissä keskusteluissa. Pienellä kielialueella jääviyteen ja anonyymisyyteen liittyvät haasteet ovat eri mittaluokkaa kuin kansainvälisillä areenoilla. Kiperä ongelma, joka vie julkaisuprosessista usein eniten aikaa, on sopivien vertaisarvioijien löytäminen. Jostain olisi otettava resursseja myös vertaisarvioitsijoiden tekemän työn palkitsemiseen. Esille on tullut myös avoimen vertaisarvioinnin mukanaan mahdollisesti tuoma toimittajien työn lisääntyminen. Yhdeksi ratkaisuksi vallitsevaan epätasapainoon on vastikään ehdotettu sekä vertaisarvioinnin että toimitustyön palkitsemista artikkelien tapaan Jufo-pisteillä (lkonen 20।8).

Vertaisarvioinnilla yhtenä julkaisemisen osa-alueena on nimenomaan laadunvarmentamiseen liittyvä tehtävä, mutta enenevässä määrin siitä puhutaan myös osana tutkijan meritoitumista.Tiedettä ei ole ilman vertaisarvioituja lehtiä ja kirjoja, ja tällä hetkellä vastuu vertaisarvioinnista on tieteellisten lehtien ja niiden kehitystyön varassa.Tieteellisten lehtien ja yliopistojen välillä vallitsee symbioottinen suhde, jossa yliopistot ovat ulkoistaneet laadunvalvonnan tieteellisille julkaisukanaville (Ilva \& Lilja 20।4, 9, 67). Tiedeyhteisön tekemän vapaaehtoistyön merkitystä ei voi yliarvioida, mutta kysymykseksi jää, kuinka sitoutumista ja motivaatiota kyetään ylläpitämään myös tulevaisuudessa.

\section{Avoin vertaisarviointi kotimaisen tiedejulkaisemisen kentällä}

\section{Kysely tiedekentän toimijoille}

Suhtautuminen avoimeen julkaisemiseen riippuu tieteenalaperinteistä ja -kulttuureista.Tämän monimuotoisuuden vuoksi on oleellista kerätä tietoa kentän toimijoilta ja avata keskustelu siitä, miten avoin vertaisarviointi ymmärretään ja minkälaisena sen merkitys ja vaikuttavuus nähdään. Missä kohtaa julkaisuprosessia työtä arvioidaan ja kommentoidaan? Haluavatko tutkijat ryhtyä vertaisarvioijiksi, jos arviointi tapahtuu omalla nimellä? Onko vertaisarvioinnin tehtävä tieteellisen meriitin tuottaminen? Lasketaanko vertaisarviointi osaksi tutkimustyötä vai onko se enemmänkin yhteiskunnallista vaikuttamista?Ymmärretäänkö vertaisarviointi yksittäiseksi tapahtumaksi vai tieteellistä keskustelua edesauttavaksi dialogiseksi prosessiksi? Tehokkaiden ja vastuullisten käytäntöjen kehittäminen on mahdollista vain, jos kaikki tarpeellinen tieto on saatavilla ja sitä voidaan punnita ja koetella keskusteluissa.

Kyselyssä selvitettiin avoimen vertaisarvioinnin tilannetta Suomessa. Miten nykyisen vertaisarviointiprosessin koetaan toimivan: onko kotimainen tiedekenttä tyytyväinen vai tyytymätön vallitseviin käytänteisiin ja miksi? Onko vastaajilla kokemusta avoimesta vertaisarvioinnista? Halusimme kyselyssä nostaa esiin tiedetoimittajien, kirjoittajien ja vertaisarvioijien näkemykset nykytilasta ja mahdollisista suunnista.

Kysely kohdistettiin lehtien toimituskunnille, ja jakelu organisoitiin Tieteellisten seurain valtuuskunnan (TSV) kautta tieteellisille seuroille, joiden julkaisutoiminnalle on myönnetty valtionavustusta. Tämän lisäksi kyselyä jaettiin avoimesti sosiaalisen median kautta, jotta se tavoittaisi mahdollisimman monta kohderyhmään kuuluvaa. Kysely oli avoinna II.6.-I.7.20I8.Vastaajat pystyivät valitsemaan suomenkielisen, ruotsinkielisen ja englanninkielisen kyselyn väliltä. Kyselyyn tuli 108 loppuun asti täytettyä vastausta, joista I0I suomenkieliseen versioon, 5 ruotsinkieliseen versioon ja 2 englanninkieliseen versioon.

Kysely jakaantui taustoittaviin kysymyksiin ja yleiseen vertaisarvioprosessia koskevan tyytyväisyyden kartoittamiseen sekä kysymyksiin avoimesta vertaisarvioinnista. Lopuksi kysyimme osallistujilta näkemyksiä myös tulevaisuuden suuntaviivoista 
suhteessa avoimeen vertaisarviointiin osana avointa tiedettä. Kyselyssä oli myös muutama vapaatekstikenttä, mutta niistä saadut vastaukset eivät ole tässä selvityksessä mukana, vaan keskitymme asteikkokysymyksiin. Kyselyä luodessamme tukeuduimme kansainvälisiin aiheesta käytyihin keskusteluihin. Keskeisimmät niistä näkökulmastamme olivat OpenAIRE2020 ja OpenUP-hankkeet (Ross-Hellauer, Deppe, Schmidt 2017; Stančiauskas \& Banelytė 2017). Otimme niistä mukaan oman selvityksemme kannalta soveltuvat kysymykset, minkä lisäksi tuotimme nimenomaan suomalaiseen kontekstiin liittyviä kysymyksiä. Lopuksi kyselystä tehtiin englanninkielisen version lisäksi käännökset suomeksi ja ruotsiksi.

\section{Taustakysymykset}

Kyselyn alussa kartoitimme vastaajien tieteenaloja. Käytimme samaa tieteenalaluokitusta, jota TSV käyttää julkaisujen luokittelemiseen JUFO-portaalissa. Luokittelussa on seitsemän päätieteenalaluokkaa, joiden alla on yhteensä 65 tieteenalaa.Vastaajia Pyydettiin valitsemaan I-3 läheisintä tieteenalaa laskevassa järjestyksessä.Vastaukset on esitetty taulukossa 2 .Yli puolet vastaajista $(51,9 \%)$ ilmoitti humanistisiin tieteisiin kuuluvan tieteenalan läheisimmäksi tieteenalakseen. Parhaiten edustettuina olivat historia ja arkeologia (20,4\%), kirjallisuudentutkimus (10,2\%) ja kielitieteet $(7,4 \%) .36,1 \%$ vastaajista ilmoitti yhteiskuntatieteisiin kuuluvan tieteenalan läheisimmäksi. Näistä parhaiten edustettuina olivat sosiologia (7,4\%), media- ja viestintätieteet $(6,5 \%)$ ja muut yhteiskuntatieteet $(6,5 \%)$. Muut tieteenalaluokat olivat vain vähäisissä määrin vastaajien ensisijaisina tieteenaloina: luonnontieteet (6\%), lääke- ja terveystieteet $(3,7 \%)$, maatalous- ja metsätieteet $(1,9 \%)$ sekä tekniikka $(0,9 \%)$.

\begin{tabular}{|l|l|l|l|l|l|l|}
\hline Tieteenala & $\begin{array}{l}\text { Lähin } \\
\text { tieteenala }\end{array}$ & $\%$ & $\begin{array}{l}\text { 2. lähin } \\
\text { tieteenala }\end{array}$ & \% & $\begin{array}{l}\text { 3. lähin } \\
\text { tieteenala }\end{array}$ & \% \\
\hline Luonnontieteet & 6 & $6 \%$ & 5 & $7 \%$ & 1 & $3 \%$ \\
\hline Tekniikka & 1 & $1 \%$ & 0 & $0 \%$ & 2 & $5 \%$ \\
\hline Lääke- ja terveystieteet & 4 & $4 \%$ & 4 & $6 \%$ & 2 & $5 \%$ \\
\hline Maatalous- ja metsätieteet & 2 & $2 \%$ & 0 & $0 \%$ & 0 & $0 \%$ \\
\hline Yhteiskuntatieteet & 39 & $36 \%$ & 28 & $41 \%$ & 20 & $53 \%$ \\
\hline Humanistiset tieteet & 56 & $52 \%$ & 32 & $46 \%$ & 13 & $34 \%$ \\
\hline Muut & 0 & $0 \%$ & 0 & $0 \%$ & 1 & $3 \%$ \\
\hline Vastauksia yhteensä & 108 & $100 \%$ & 69 & $100 \%$ & $39 \%$ & $100 \%$ \\
\hline
\end{tabular}

\section{Taulukko 2 - Vastaajien ensisijaiset tieteenalat}

Seuraavassa kysymyksessä kartoitettiin, minkä sektorin organisaatioissa vastaajat päätoimisesti työskentelevät. Vastaajista $74 \%$ työskenteli yliopistossa, $6 \%$ tutkimuskeskuksessa tai tutkimusinstituutissa, $6 \%$ tieteellisessä seurassa, $1 \%$ yksityisessä yrityksessä ja $12 \%$ muussa organisaatiossa. $2 \%$ vastaajista ei osannut vastata kysymykseen.

Kysyimme myös vastaajien tutkimuskokemusta, sillä halusimme tietää, miten kokeneita vastaajat ovat tieteellisen toiminnan ja julkaisemisen kontekstissa.Vastaajien jakauma on esitetty taulukossa 3 . Suurella osalla, $77 \%$ vastaajista, oli vähintään tohtorin tutkinnon verran tutkimuskokemusta, ja muutenkin statukseltaan itsenäiset ja johtavat tutkijat olivat vahvasti edustettuina: 


\begin{tabular}{|l|c|c|}
\hline Tutkimuskokemus & N & $\%$ \\
\hline Ylempi korkeakoulututkinto tai vastaava & 10 & $9 \%$ \\
\hline Tohtorikoulutettava tai vastaava & 10 & $9 \%$ \\
\hline Tohtorintutkinto tai vastaava & 23 & $21 \%$ \\
\hline $\begin{array}{l}\text { Itsenäinen tutkija (esim. apulaisprofessori, yliopiston- } \\
\text { lehtori, vanhempi tutkija) }\end{array}$ & 37 & $34 \%$ \\
\hline Johtava tutkija (professoritaso) & 24 & $22 \%$ \\
\hline Muu (täsmennä) & 4 & $4 \%$ \\
\hline Vastauksia yhteensä & 108 & $100 \%$ \\
\hline
\end{tabular}

\section{Taulukko 3 - Vastaajien tutkimuskokemus}

Taustakysymyksiin kuului myös kysymys, jossa tiedusteltiin vastaajien käyttämiä kieliä tieteellisessä toiminnassaan. Taulukko 4 kokoaa nämä vastaukset. $51 \%$ vastaajista ilmoitti pääasialliseksi kielekseen suomen, $46 \%$ englannin, $2 \%$ ruotsin ja I\% venäjän kielen. Viittä vastaajaa lukuun ottamatta vastaajat ilmoittivat myös toisen, vähemmän käytetyn kielen, ja yli puolet vastaajista (55) myös kolmannen kielen. Toisena kielenä suomi ja englanti olivat vahvasti edustettuina. Kolmantena kielenä dominoi ruotsi $29 \%$ osuudella.

\begin{tabular}{|l|c|c|c|c|c|c|}
\hline $\begin{array}{l}\text { Pääasialliset kielet, joita käy- } \\
\text { tät tieteellisessä toiminnassa- } \\
\text { si (eniten käytetystä vähiten } \\
\text { käytettyyn) }\end{array}$ & I. & $\%$ & 2. & $\%$ & 3. & $\%$ \\
\hline Suomi & 55 & $51 \%$ & 37 & $36 \%$ & 7 & $13 \%$ \\
\hline Englanti & 50 & $46 \%$ & 52 & $50 \%$ & 4 & $7 \%$ \\
\hline Ruotsi & 2 & $2 \%$ & 5 & $5 \%$ & 31 & $56 \%$ \\
\hline Venäjä & 1 & $1 \%$ & 1 & $1 \%$ & 2 & $4 \%$ \\
\hline Italia & 0 & $0 \%$ & 1 & $1 \%$ & 0 & $0 \%$ \\
\hline Saksa & 0 & $0 \%$ & 4 & $4 \%$ & 2 & $4 \%$ \\
\hline Ranska & 0 & $0 \%$ & 2 & $2 \%$ & 5 & $1 \%$ \\
\hline Hollanti & 0 & $0 \%$ & I & $1 \%$ & 0 & $0 \%$ \\
\hline Interlingua & 0 & $0 \%$ & 0 & $0 \%$ & 1 & $2 \%$ \\
\hline Norja & 0 & $0 \%$ & 0 & $0 \%$ & 1 & $2 \%$ \\
\hline Viro & 108 & $100 \%$ & 103 & $100 \%$ & 55 & $100 \%$ \\
\hline Puola & 0 & 0 & $0 \%$ & 1 & $2 \%$ \\
\hline Vastauksia yhteensä & $0 \%$ & 0 & $0 \%$ & 1 & $2 \%$ \\
\hline
\end{tabular}

Taulukko 4 - Vastaajien pääasialliset kielet tieteellisessä toiminnassa 
Halusimme myös selvittää vastaajien mahdollisia tehtäviä tieteellisissä seuroissa.

Vastausten perusteella II\% oli aktiivisia toimihenkilöitä, 39\% hallituksen jäseniä sekä

$51 \%$ lehden toimituskunnan jäseniä. Koska yhdellä henkilöllä voi olla monta tehtävää

seuran sisällä, taulukko 5 esittää tarkemmin tehtävien jakautumisen vastaajien kesken:

\begin{tabular}{|l|c|c|}
\hline Tehtävät tieteellisessä seurassa & N & $\%$ \\
\hline $\begin{array}{l}\text { Vastaajalla ei tehtävää kotimaisessa tieteellisessä } \\
\text { seurassa }\end{array}$ & 29 & $27 \%$ \\
\hline Vain toimihenkilönä & 5 & $5 \%$ \\
\hline Vain hallituksen jäsenenä & 28 & $26 \%$ \\
\hline Lehden toimituskunnan jäsen & 23 & $21 \%$ \\
\hline Toimihenkilö + hallituksen jäsen & 2 & $2 \%$ \\
\hline Toimihenkilö + lehden toimituskunnan jäsen & 1 & $1 \%$ \\
\hline Hallituksen jäsen + lehden toimituskunnan jäsen & 16 & $15 \%$ \\
\hline Kaikki kolme tehtävää & 4 & $4 \%$ \\
\hline Vastauksia yhteensä & 108 & $100 \%$ \\
\hline
\end{tabular}

Taulukko 5 - Vastaajien mahdolliset tehtävät tieteellisessä seurassa 
Lehtiartikkelit (kotimaiset tiedelehdet)

Lehtiartikkelit (kansainväliset tiedelehdet, ei Suomessa toimivat

Konferenssijulkaisut

Monografiat

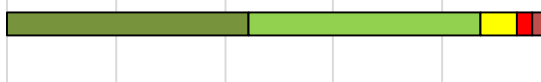

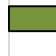

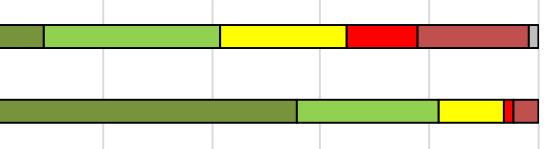

Tieteellisissä kokoomateoksissa julkaistut artikkelit

Muut tuotokset (täsmennä) $(\mathrm{N}=11)$

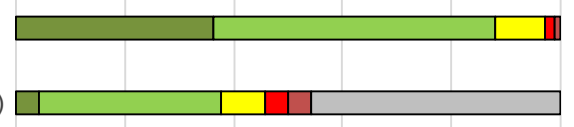

口Erittäin tärkeä

口Jokseenkin tärkeä

घJokseenkin vähämerkityksinen घVähämerkityksinen

口Ei tärkeä eikä vähämerkityksinen 口En tiedä / en osaa vastata

\section{Kuva I - Eri julkaisukanavien koettu tärkeys omalla tieteenalalla}

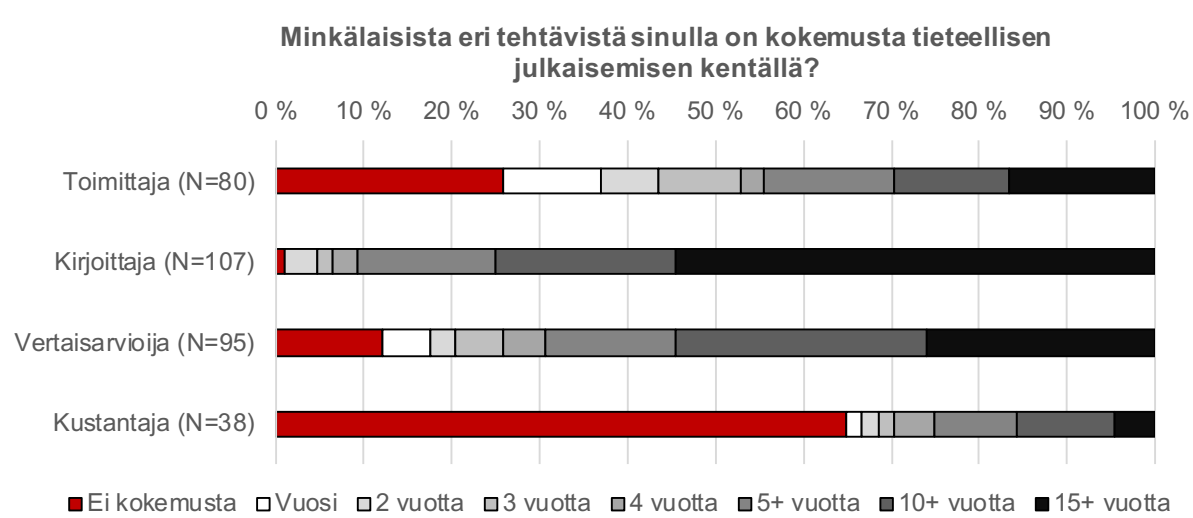

Kuva 2 - Kokemus tieteellisen julkaisemisen tehtävistä
Julkaisukulttuurit ja tieteellisen viestinnän käytännöt eroavat tieteenalojen välillä. Kysely ei ollut rajattu vain tietylle tieteenalalle, minkä takia pyysimme vastaajia ilmoittamaan erilaisten julkaisukanavien merkityksen omalla tieteenalallaan. Kuvassa I esitetään tiivistettynä kysymykseen saadut vastaukset. Tuloksista selviää, että kansainväliset tiedelehdet nähdään kaikkein tärkeimpänä julkaisukanavana, jonka jälkeen tulevat kotimaiset tiedelehdet, tieteellisissä kokoelmateoksissa julkaistut artikkelit sekä monografiat. Konferenssijulkaisut nähtiin yleisesti vähiten tärkeinä. Muita tuotoksia ilmoitti I I vastaajaa, jolloin mainintoja saivat muun muassa yleistajuiset ja popularisoidut tekstit sekä blogikirjoitukset. Tässä yhteydessä on hyvä pitää mielessä, että $88 \%$ vastaajista oli ilmoittanut lähimmäksi tieteenalakseen humanistisiin tieteisiin tai yhteiskuntatieteisiin luokitellun tieteenalan.

Halusimme saada myös paremman käsityksen vastaajien kokemusten laajuudesta tieteellisen julkaisemisen kentällä. Sen vuoksi pyysimme vastaajia ilmoittamaan, miten pitkään he ovat toimineet toimittajan, kirjoittajan, vertaisarvioijan ja kustantajan tehtävissä. Kuvasta 2 selviää, että kaikkein eniten kokemusta vastaajilla oli kirjoittajan roolissa toimimisesta. Yli $90 \%$ vastaajista oli yli 5 vuoden kokemus kirjoittajan roolista ja vain prosentilla vastaajista ei ollut kokemusta tästä tehtävästä. Toiseksi yleisin tehtävä oli vertaisarviointi, josta lähes $70 \%$ vastaajista oli yli 5 vuoden kokemus ja vain $12 \%$ vastaajista puuttui kokemus tästä tehtävästä.Toimittajan tehtävistä $74 \%$ vastaajista oli vähintään vuosi kokemusta. Kustantajan kokemusta löytyi 35\% vastaajista.

\section{Tyytyväisyys vallitsevaan käytäntöön}

Kyselyssä selvitettiin myös, kuinka tyytyväisiä kentällä ollaan vallitseviin vertaisarviointikäytäntöihin.Tämä kysymys esitettiin niille vastaajille, joilla oli jo kokemusta tiedejulkaisemiseen liittyvistä tehtävistä. Halusimme selvittää tyytyväisyyttä ennen kaikkea sen mukaan, miten vastaaja kokee vertaisarvioinnin eri rooleissa: vertaisarvioijana, toimittajana, kirjoittajana, kustantajana.

Kuvassa 3 esitetään, miten vastaajien tyytyväisyys jakautui eri tehtävien mukaan. Tehtävien kesken vaihtelu oli suhteellisen vähäistä.Tehtävästä riippumatta alle $10 \%$ oli erittäin tyytyväisiä, mutta suurin osa oli jokseenkin tyytyväisiä (vaihteluväli 50\%-65\% vastaajista). 
Tyytyväisyys vallitsevaan vertaisarviokäytäntöön tieteellisen julkaisemisen eri tehtävissä

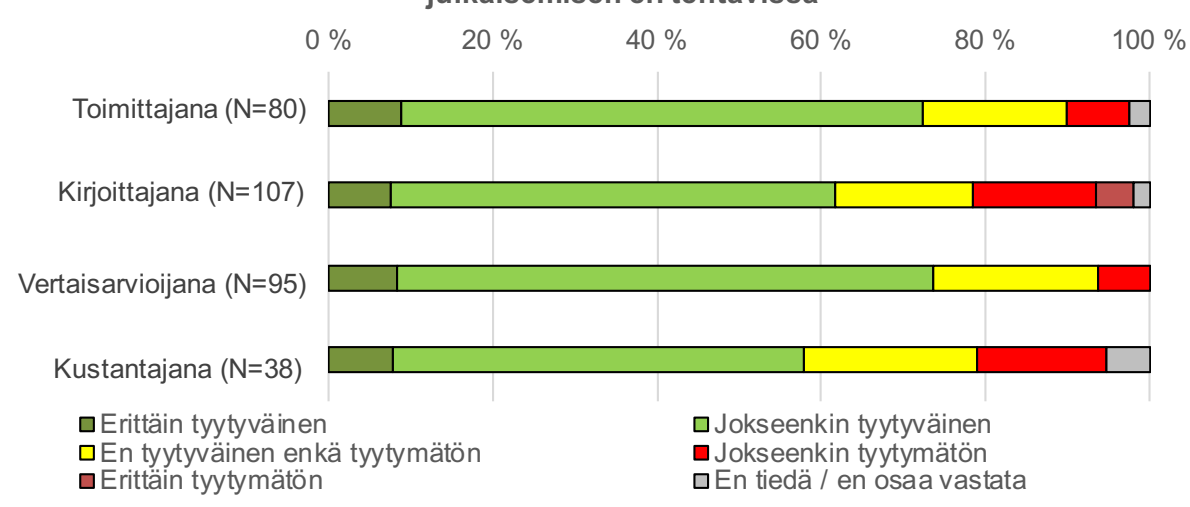

Kuva 3 - Tyytyväisyys vallitsevaan vertaisarviointikäytäntöön

Mitä mieltä olet vertaisarvioijana seuraavista väitteistä? ( $\mathrm{N}=95$ )

$\begin{array}{llllll}0 & 0\end{array} \quad 20 \% \quad 40 \% \quad 60 \% \quad 80 \% \quad 100 \%$

Työtäni vertaisarvioijana arvostetaan ja arvioidaan organisaatiossa, jossa työskentelen

Työni vertaisarvioijana hyödyttää urakehitystäni

Haluni toimia vertaisarvioijana lisääntyisi, jos vertaisarviolausuntoni julkaistaisiin nimelläni

Haluni toimia vertaisarvioijana lisääntyisi, jos saisin
työstäni korvausta

Haluni toimia vertaisarvioijan lisä̈n vuorovaikutus kirjoittaiien, toimittajien ja kustantajan välillä paranisi
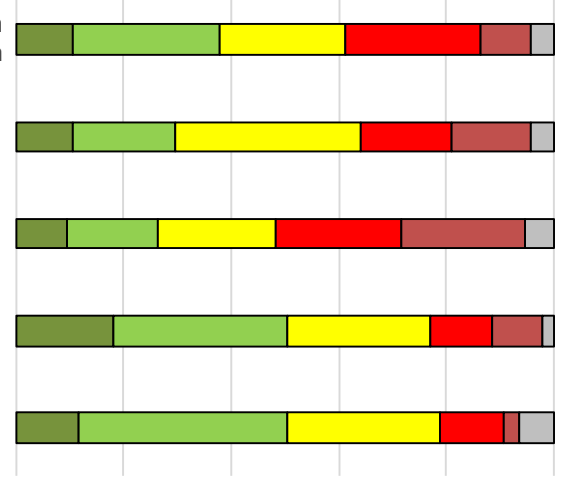

口Täysin samaa mieltă

口Jokseenkin samaa mieltä

口Ei samaa eikä eri mieltä
Kyselyssä oli jokaiseen tehtävään liittyen jatkokysymyksiä, joiden tavoitteena oli saada selville tarkemmin, mitkä asiat ovat ongelmallisia nykyisissä käytännöissä.Vertaisarvioijan tehtävään liittyvät jatkokysymykset esitettiin kaikille, joilla oli tehtävästä kokemusta. Muita kolmea tehtävää (toimittaja, kirjoittaja, kustantaja) koskevat kysymykset esitettiin ainoastaan niille, jotka olivat vastanneet neutraalisti tai negatiivisesti tyytyväisyyttä koskeviin kysymyksiin. Seuraavaksi esitetään näiden jatkokysymysten tulokset tehtäväkohtaisesti.

Vertaisarvioijan näkökulma

I08 vastaajasta 95:Ilä (88\%) oli kokemusta vertaisarviojana toimimisesta, ja näitä vastaajia pyydettiin ottamaan kantaa viiteen vertaisarviointia koskevaan väitteeseen. Kuvassa 4 on esitetty tulokset, joista selviää, että mielipiteet jakautuvat melko vahvasti.

Väitteet "Työtäni vertaisarvioijana arvostetaan ja arvioidaan organisaatiossa, jossa työskentelen", "Työni vertaisarvioijana hyödyttää urakehitystäni” ja "Haluni toimia vertaisarvioijana lisääntyisi, jos vertaisarviolausuntoni julkaistaisiin nimelläni” saivat melko lailla toisiaan vastaavia vastausprofiileja, joissa noin $10 \%$ vastaajista oli täysin samaa mieltä, $16 \%-27 \%$ jokseenkin samaa mieltä, $22 \%-35 \%$ ei samaa eikä eri mieltä, I7\%-25\% jokseenkin eri mieltä ja 9\%-23\% täysin eri mieltä. Noin 5\% ei tiennyt tai ei osannut vastata.

Väitteet "Haluni toimia vertaisarvioijana lisääntyisi, jos saisin työstäni korvausta" ja "Haluni toimia vertaisarvioijana lisääntyisi, jos vuorovaikutus kirjoittajien, toimittajien ja kustantajan välillä paranisi” saivat vastaajilta suurin piirtein samanlaisen reaktion: $50 \%$ oli täysin tai samaa mieltä väitteiden kanssa, noin 30\% ei samaa eikä eri mieltä ja $15 \%$ $20 \%$ jokseenkin tai täysin eri mieltä. Noin $5 \%$ ei tiennyt tai ei osannut vastata.

\section{Toimittajan näkökulma}

Vastaajista toimittajan roolissa oli toiminut 80, josta 20 (25\%) oli vastannut olevansa "tyytymättömiä", "jokseenkin tyytymättömiä", tai "ei tyytyväisiä eikä tyytymättömiä" vallitsevaan vertaisarviokäytäntöön. Kuvassa 5 esitetään, miten tärkeinä nämä 20 vastaajaa näkivät erilaiset syyt varaukselliseen mielipiteeseensä (ks. kuva 5.). Vastaajia pyydettiin ottamaan kantaa vertaisarvion laatuun, kestoon, läpinäkyvyyteen sekä kommunikaatioon tai sen puutteeseen. "Muut syyt" -kohdassa vastaajat mainitsivat henkilösuhteiden tärkeyden, ajan, joka toimittajilla menee arvioijien etsimiseen sekä huomion siitä, että kahden ulkopuolisen arvio ei lähtökohtaisesti ole laadun tae.

\section{Kuva 4 - Mielipiteitä vertaisarvioijana toimimisesta}


Kuinka tärkeänä suhtautumiseesi koet seuraavassa luetellut syyt? Kysymys esitetty vastaajille jotka ilmoittivat olevansa toimittajina "tyytymättömiä", "joksenkin tyytymättömiä" tai "ei tyytyväisiä eikä tyytymättömiä" vallitsevaan vertaisarviokäytäntöön.

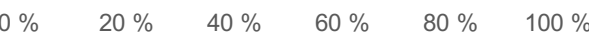

Vertaisarviolausuntojen laat

Vertaisarviointiin kuluva aik

Läpinäkyvyyteen liittyvät tekijät ja avoimuuden puute prosessissa

Kirjoittajien ja vertaisarvioijien välisen tieteellisen kommunikaation puute

Muut syyt (täsmennä) $(\mathrm{N}=5)$

口Erittäin tärkeä

口Jokseenkin tärkeä

घJokseenkin vähämerkityksinen घVähämerkityksinen

口Ei tärkeä eikä vähämerkityksinen

口En tiedä / en osaa vastata

\section{Kuva 5 - Varauksellisuus vallitsevaa vertaisarviointikäytäntöä kohtaan} toimittajan näkökulmasta

Kuinka tärkeänä suhtautumiseesi koet seuraavassa luetellut syyt? Kysymys esitetty vastaajille jotka ilmoittivat olevansa kirjoittajina "tyytymättömiä", "joksenkin tyytymättömiä" tai "ei tyytyväisiä eikä tyytymättömiä" vallitsevaan vertaisarviokäytäntöön.

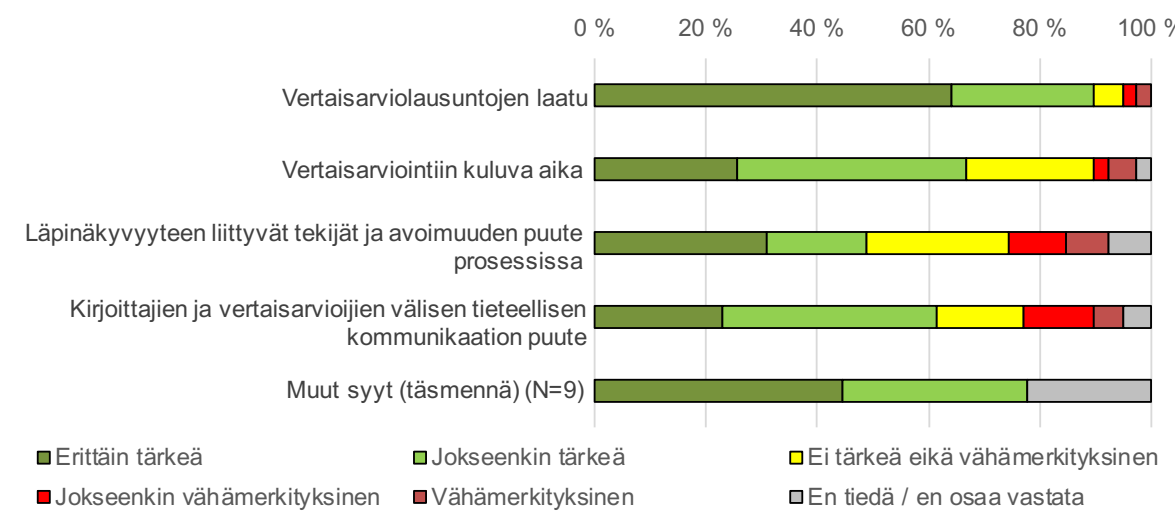

Kuva 6 - Varauksellisuus vallitsevaa vertaisarviointikäytäntöä kohtaan kirjoittajan näkökulmasta
Kolme vastaajaa oli vastannut tähän kohtaan ”En tiedä/en osaa vastata”.

\section{Kirjoittajan näkökulma}

Vastaajista kirjoittajan roolissa oli toiminut I07, josta 39 (36\%) oli vastannut olevansa "tyytymättömiä", "jokseenkin tyytymättömiä", tai "ei tyytyväisiä eikä tyytymättömiä" vallitsevaan vertaisarviokäytäntöön. Kuvassa 6 esitetään, miten tärkeinä nämä 39 vastaajaa näkivät erilaiset syyt varaukselliseen mielipiteeseensä.

Kaikkein tärkein syy vastaajien kesken oli vertaisarvioiden koettu laatu $(90 \%$ mielestä erittäin tärkeä tai jokseenkin tärkeä), toiseksi tärkein vertaisarviointiin kuluva aika (66\% mielestä erittäin tärkeä tai jokseenkin tärkeä), kolmanneksi kirjoittajien ja vertaisarvioijien välisen tieteellisen kommunikaation puute $(62 \%$ mielestä erittäin tärkeä tai jokseenkin tärkeä) sekä viimeisenä läpinäkyvyyteen liittyvät tekijät ja avoimuuden puute prosesseissa (49\% mielestä erittäin tärkeä tai jokseenkin tärkeä). Muina syinä vastaajat ilmoittivat seuraavia seikkoja: henkilösuhteet vaikuttavat liikaa, monitieteisen julkaisun vertaisarvioinnin vaikeus, lehden toimitustyön laatu, lausuntojen ilkeys ja asiantuntemattomuus, pyrkimys objektiivisuuteen vertaisarvioinnissa, luottamus, lehtien artikkelikäytäntöjen erot ja joustamattomuus. Kaksi vastaajaa oli vastannut "En tiedä / en osaa vastata" ilman erikseen syötettyä syytä.

Kustantajan näkökulma

Vastaajista kustantajan roolissa oli toiminut 38, joista I 4 (37\%) oli vastannut olevansa "tyytymättömiä", "jokseenkin tyytymättömiä", tai "ei tyytyväisiä eikä tyytymättömiä" vallitsevaan vertaisarviokäytäntöön. Kuvassa 7 esitetään, miten tärkeinä nämä 14 vastaajaa näkivät erilaiset syyt varaukselliseen mielipiteeseensä. 
Kuinka tärkeänä suhtautumiseesi koet seuraavassa luetellut syyt? Kysymys esitetty vastaajille jotka ilmoittivat olevansa kustantajina "tyytymättömiä", "joksenkin tyytymättömiä" tai "ei tyytyväisiä eikä tyytymättömiä" vallitsevaan vertaisarviokäytäntöön. (

\section{$\begin{array}{llllll}0 & 20\end{array} \quad 40 \% \quad 60 \% \quad 80 \% \quad 100 \%$}

Vertaisarviolausuntojen laatu

Vertaisarviointiin kuluva aika

Läpinäkyvyyteen liittyvät tekijät ja avoimuuden puute

Kirjoittajien ja vertaisarvioijien välisen tieteellisen kommunikaation puute

Muut syyt (täsmennä) (N=4)
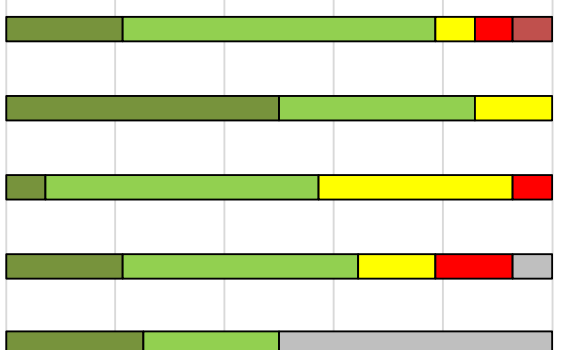

¿Erittäin tärkeä

口Jokseenkin tärkeä

口Ei tärkeä eikä vähämerkityksinen

匹 Jokseenkin vähämerkityksinen घVähämerkityksinen

口En tiedä / en osaa vastata

\section{Kuva 7 - Varauksellisuus vallitsevaa vertaisarviointikäytäntöä kohtaan kustantajan näkökulmasta}

\section{Avoimen vertaisarvioinnin asteet}

Taustakysymysten jälkeen kyselyssä oli osio, joka käsitteli mielipiteitä ja kokemuksia avoimesta vertaisarvioinnista. Ensimmäisenä kysymyksenä kartoitettiin vastaajien kokemuksia avoimesta vertaisarvioinnista eri julkaisemisen tehtävissä.Vastaukset on visualisoitu kuvassa 8 .

Avoimen vertaisarvioinnin elementeistä kaikilla vastaajaryhmillä oli eniten kokemusta avoimista identiteeteistä. Tehtävästä riippuen toisella tai kolmannella sijalla olivat tämän jälkeen avoin vuorovaikutus ja avoin osallistuminen. Kaikkein vähiten kokemusta vastaajilla oli avoimista lausunnoista lukuun ottamatta vertaisarvioijan roolia, jossa kyseinen elementti oli jaetulla kolmannella sijalla avoimen vuorovaikutuksen kanssa.

\section{Avoimet vertaisarviolausunnot}

Kokemusten kartoittamisen jälkeen kaikille vastaajille esitettiin kysymyksiä avoimista vertaisarviolausunnoista. Vastaukset nähin kysymyksiin on tiivistetty kuvaan 9.
Onko sinulla kokemusta avoimesta vertaisarvioinnista joissakin seuraavista rooleista?

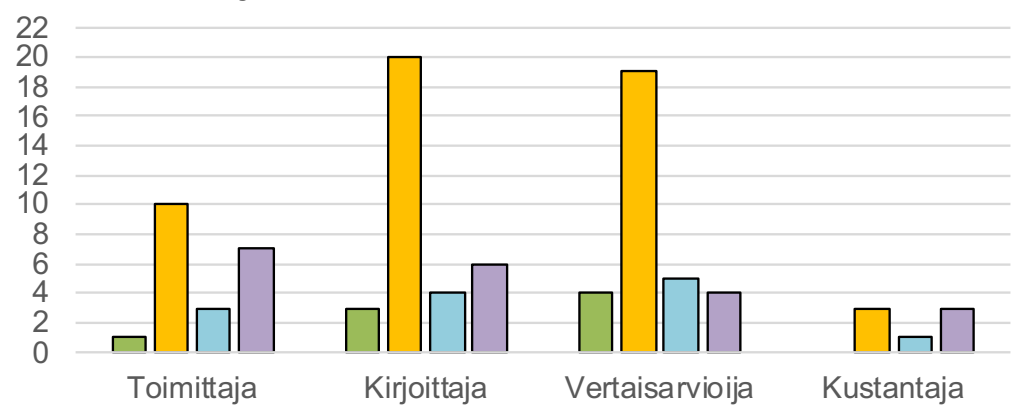

$\square$ Avoimet lausunnot: vertaisarviointi, jossa vertaisarviolausunnot julkaistaan julkaistavan artikkelin rinnalla

$\square$ Avoimet identiteetit: vertaisarviointi, jossa kirjoittajat ja arvioijat ovat selvillä toistensa henkilöllisyydestä

$\square$ Avoin osallistuminen: vertaisarviointi, jossa arviointiprosessiin ottaa osaa laajempi yhteisö

$\square$ Avoin vuorovaikutus: vertaisarviointi, joka sallii kirjoittajan ja vertaisarvioijan tai vertaisarvioijien välisen kommunikaation ja rohkaisee siihen

\section{Kuva 8 - Vastaajien kokemukset avoimesta vertaisarvioinnista eri julkai- semisen tehtävissä}

Vastausten perusteella havaitaan, että suurin osa vastaajista näki lausuntojen julkaisemisesta olevan jonkinlaista hyötyä.Avaaminen vaikuttaa kuitenkin todennäköisesti siihen, kuinka houkuttelevaksi vertaisarvioijat ja kirjoittajat kokevat lehteen kontribuoimisen.

Väitteet "Julkaistut vertaisarviolausunnot tarjoavat lukijalle hyödyllistä tietoa", ”Jos vertaisarviolausunnot julkaistaan, vertaisarvioijat eivät enää esitä yhtä voimakasta kritiikkiä", ja "Julkaiseminen parantaa vertaisarviolausuntojen laatua" saivat suurin piirtein samanlaiset vastausprofilit: $48 \%-60 \%$ oli joko täysin samaa tai samaa mieltä väitteiden kanssa, ja täysin eri mieltä tai eri mieltä oli 17\% vastaajista.

Kirjoittajille ja arvioijille esitettiin kaksi väitettä houkuttelevuudesta: I. "Vertaisarvioijat kieltäytyvät tehtävästä helpommin, jos lausunnot julkaistaan" ja 2. "Kirjoittajat eivät tarjoa artikkeleitaan lehtiin, jotka julkaisevat vertaisarviolausunnot". Nämä 
väitteet saivat toisistaan hyvin poikkeavat vastausprofiilit.Vastaajat näkivät, että avoimet arviot aiheuttavat suuremman ongelman vertaisarvioitsijoita rekrytoitaessa $(57 \%$ täysin samaa tai samaa mieltä väitteen kanssa, $16 \%$ täysin eri mieltä tai eri mieltä väitteen kanssa) kuin kirjoittajien houkuttelemisessa ( $18 \%$ täysin samaa tai samaa mieltä väitteen kanssa, 31\% täysin eri mieltä tai eri mieltä väitteen kanssa).

Tämän kysymyksen kohdalla on huomattava, että väittämästä riippuen melko suuri osa, $7 \%-20 \%$ vastaajista, oli päätynyt vaihtoehtoon "En tiedä / en osaa vastata".

\section{Avoimet identiteetit}

Seuraavaksi kaikille vastaajille esitettiin avoimiin identiteetteihin liittyviä kysymyksiä. Vastaukset näihin kysymyksiin on tiivistetty kuvaan 10.

Kuten edellisen kysymyksen kohdalla, myöskään tässä tulokset eivät ole yksiselitteisiä: vastauksista ilmenee, että avoimuuden lisääminen sisältäisi sekä uusia hyötyjä että haasteita.Väittämä "Vertaisarvioijat kieltäytyvät tehtävästä helpommin, jos henkilöllisyys paljastetaan" sai vastaajilta kaikkein vahvimman kannatuksen: $56 \%$ oli väittämän kanssa samaa mieltä tai täysin samaa mieltä, $16 \%$ oli eri mieltä tai täysin eri mieltä.Toisaalta toiseksi eniten kannatusta saanut väittämä oli "Vertaisarvioijan identiteetin paljastaminen parantaa vertaisarviolausuntojen laatua": $54 \%$ oli väittämän kanssa samaa mieltä tai täysin samaa mieltä, $19 \%$ oli eri mieltä tai täysin eri mieltä.

Väittämästä "Jos vertaisarvioijan identiteetti paljastetaan, vertaisarvioija ei enää esitä yhtä voimakasta kritiikkiä" $52 \%$ vastaajista oli samaa mieltä tai täysin samaa mieltä, $23 \%$ oli eri mieltä tai täysin eri mieltä.Väitteestä "Vertaisarvioijien pitäisi saada valita, paljastaako henkilöllisyytensä vai ei" $52 \%$ oli väittämän kanssa samaa mieltä tai täysin samaa mieltä, $27 \%$ oli eri mieltä tai täysin eri mieltä.Väitteeseen "Kirjoittajat eivät tarjoa artikkeleitaan lehtiin, jotka paljastavat vertaisarvioijien henkilöllisyyden" vain $8 \%$ oli väittämän kanssa samaa mieltä tai täysin samaa mieltä, $45 \%$ oli eri mieltä tai täysin eri mieltä.

Väitteeseen "Vertaisarvioijan henkilöllisyyden paljastaminen on reilua kirjoittajaa kohtaan" vastaukset olivat melko tasapuolisesti väittämän puolesta ja vastaan (36\% samaa mieltä tai täysin samaa mieltä, $32 \%$ eri mieltä tai täysin eri mieltä).Väitteellä oli myös tämän väiteryhmän suurin osuus neutraaleja kannanottoja ( $27 \%$ vastaajista ei samaa eikä eri mieltä).
Avoimet vertaisarviolausunnot

Mitä mieltä olet seuraavista väitteistä?

$$
0 \% \quad 20 \% \quad 40 \% \quad 60 \% \quad 80 \% \quad 100 \%
$$

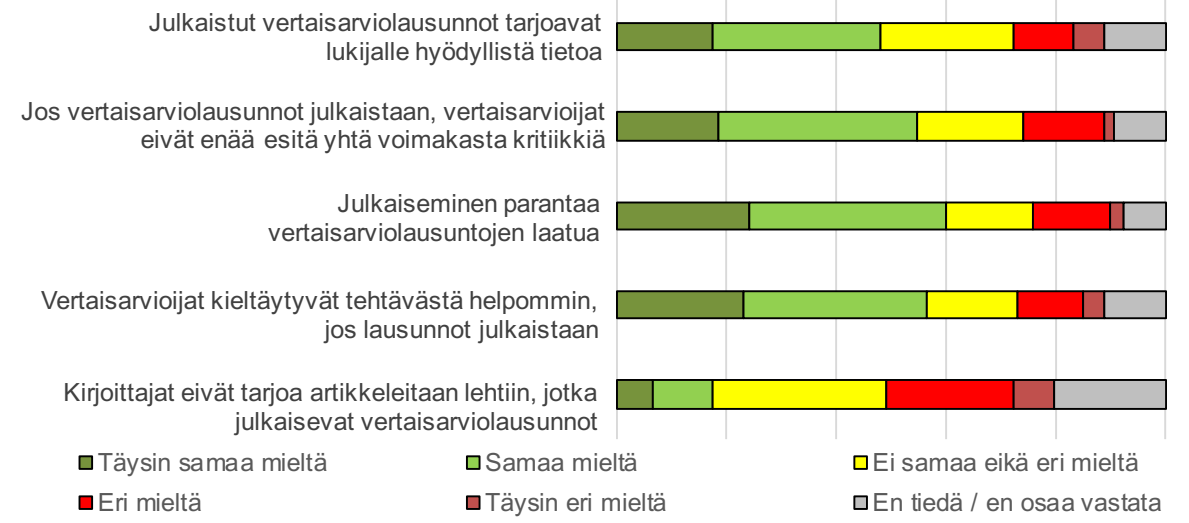

\section{Kuva 9 - Mielipiteitä avoimista vertaisarviolausunnoista}

$$
\begin{aligned}
& \text { Avoimet identiteetit } \\
& \text { - } \\
& \text { Mitä mieltä olet seuraavista väitteistä? } \\
& \begin{array}{cccccc}
0 \% & 20 \% & 40 \% & 60 \% & 80 \% & 100 \%
\end{array}
\end{aligned}
$$

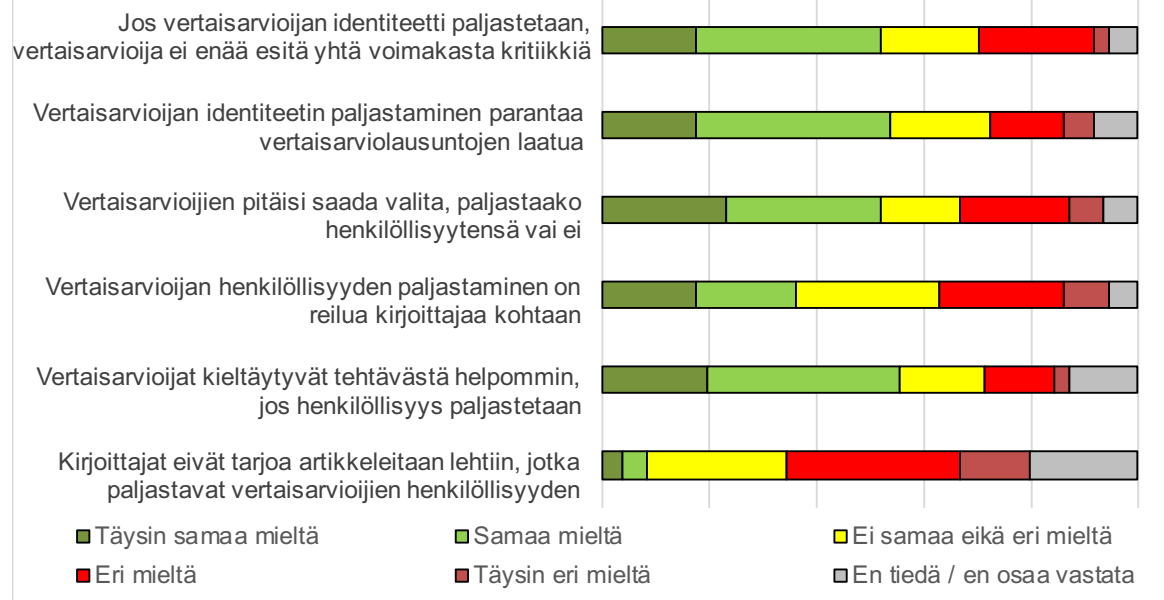

Kuva 10 - Mielipiteitä avoimista identiteeteistä 


\section{Avoin osallistuminen}

Seuraavaksi kaikille vastaajille esitettiin kolme avoimeen osallistumiseen liittyvää väittämää. Vastaukset näihin kysymyksiin on tiivistetty kuvaan II.

Väite "Vertaisarvioijat arvioivat todennäköisemmin kutsuttuina" sai kaikkein vahvinta kannatusta vastaajilta, $81 \%$ vastaajista oli tämän väittämän kanssa samaa tai täysin samaa mieltä.Vain $4 \%$ vastaajista oli eri mieltä tai täysin eri mieltä väitteen kanssa.

Väittämään "Jokaisen, jolla on tarpeellinen tietotaso, tulisi saada osallistua vertaisarviointiin huolimatta muodollisesta pätevyydestä" vastaajista $44 \%$ oli samaa tai täysin samaa mieltä, ja 33\% eri mieltä tai täysin eri mieltä.Tämän pohjalta voi tulkita, että vastaajat näkevät ainakin jonkinlaisen muodollisen pätevyyden hyödylliseksi, vaikka "tarpeellinen tietotaso" onkin hankalasti määriteltävissä.

Väitteeseen "Vertaisarvioijien ja toimittajien muodostamat sisäpiirit estävät tutkimuksen innovatiivisuutta" mielipiteiden jakautuminen puolesta ja vastaan oli hyvin tasaista (3 I\% eri mieltä tai täysin eri mieltä, 34\% samaa mieltä tai täysin samaa mieltä, loput ei samaa eikä eri mieltä tai en tiedä/en osaa vastata).

\section{Avoin vuorovaikutus}

Seuraavaksi kaikille vastaajille esitettiin neljä avoimeen vuorovaikutukseen liittyvää väittämää.Vastaukset näihin kysymyksiin on tiivistetty kuvaan 12.

Väite "'Lisääntynyt vuorovaikutus kirjoittajien ja vertaisarvioijien välillä johtaa parempiin julkaisuihin" sai kaikkein vahvinta kannatusta vastaajilta (7I\% samaa tai täysin samaa mieltä) ja hyvin vähän eriäviä mielipiteitä ( $9 \%$ eri mieltä tai täysin eri mieltä).

Väittämään "Lehtien pitäisi mahdollistaa artikkelien avoin viimeisen version kommentointi nettisivustollaan" vastaajista $39 \%$ oli eri mieltä tai täysin eri mieltä ja vain $24 \%$ oli samaa tai täysin samaa mieltä.Tämän väittämän osalta yli kolmannes vastaajista (37\%) oli valinnut en tiedä/en osaa sanoa tai en samaa enkä eri mieltä.

Väittämän "Blogiartikkelit, verkkolukupiirit sekä julkaistun artikkelin kommentointi sosiaalisen median kautta ovat osa vertaisarviointia" vastausten profiili oli enimmäkseen negatiivinen ( $37 \%$ eri mieltä tai täysin eri mieltä, $28 \%$ samaa tai täysin samaa mieltä). Tässäkin väittämässä ei samaa tai ei eri mieltä ja en tiedä/en osaa vastata vastausten osuus oli suhteellisen suuri (33\%).

Avoin osallistuminen

Mitä mieltä olet seuraavista väitteistä?

$$
\begin{array}{llllll}
0 \% & 20 \% & 40 \% & 60 \% & 80 \% & 100 \%
\end{array}
$$

Jokaisen, jolla on tarpeellinen tietotaso, tulisi saada osallistua vertaisarviointiin huolimatta muodollisesta pätevyydestä

Vertaisarvioijien ja toimittajien muodostamat sisäpirit estävät tutkimuksen innovatiivisuutta

Vertaisarvioijat arvioivat todennäköisemmin kutsuttuina
口Täysin samaa mieltä
口Samaa mieltä
口Eri mieltä
口Täysin eri mieltä
口Ei samaa eikä eri mieltä 口En tiedä / en osaa vastata

\section{Kuva I I - Mielipiteitä avoimesta osallistumisesta}

Avoin vuorovaikutus

Mitä mieltä olet seuraavista väitteistä?

$$
\begin{array}{llllll}
0 & 20
\end{array} \quad 40 \% \quad 60 \% \quad 80 \% \quad 100 \%
$$

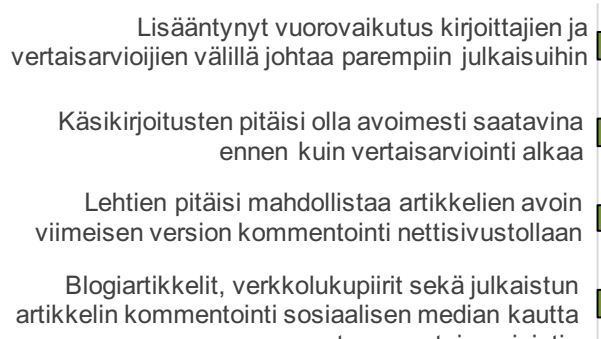

$\begin{array}{ll}\text { 口Täysin samaa mieltä } & \text { 口Eri mieltä } \\ \text { 口Täysin eri mieltä }\end{array}$

口Ei samaa eikä eri mieltä 口En tiedä / en osaa vastata

\section{Kuva I 2 - Mielipiteitä avoimesta vuorovaikutuksesta}


Väite "Käsikirjoitusten pitäisi olla avoimesti saatavina ennen kuin vertaisarviointi alkaa" herätti suurimmassa osassa vastaajissa erimielisyyttä (57\% eri mieltä tai täysin eri mieltä).Vain $12 \%$ oli väitteen kanssa samaa tai täysin samaa mieltä, mikä on pienempi osuus kuin en tiedä/en osaa vastata -vastausten osuus.

Käsityksiä tieteellisen kommunikaation kentästä suhteessa avoimeen tieteeseen Kyselyn lopuksi vastaajille esitettiin viisi kysymystä tieteellisen kommunikaation kentästä yleisesti. Kysymysten avulla yritettiin selvittää mahdollisimman suoraan, mitä mieltä vastaajat ovat avoimen tieteen osa-alueista ja niiden tulevaisuuden kehityksestä.Vastaukset ovat tiivistetty kuvaan 13.

Väitteeseen "Tieteellisen kommunikaation tämänhetkiset käytännöt toimivat kaiken kaikkiaan hyvin" vastattiin hyvin epäyhtenäisesti: suurin piirtein yhtä suuri osa oli väitteen kanssa samaa mieltä, eri mieltä ja ei samaa eikä eri mieltä (noin $30 \%$ osuus jokaisessa).

Tieteellisten julkaisujen saatavuus lähtökohtaisesti avoimena sai tämän osion väitteistä vastaajilta suurinta tukea. $82 \%$ vastaajista oli samaa tai täysin samaa mieltä "Tieteellisten julkaisujen avoin saatavuus pitäisi olla yleinen käytäntö" väitteen kanssa, ja vain $7 \%$ oli eri mieltä tai täysin eri mieltä väitteen kanssa.

Myös tutkimusdatan avoimuus sai vastaajilta vahvaa kannatusta.Väitteen "Tutkimusdatan tulisi olla lähtökohtaisesti aina avointa ja vain perustelluista syistä (kuten aineiston sensitiivisyys) rajautua esim. pelkkiin keskeisiin metatietoihin" kanssa $66 \%$ vastaajista oli samaa tai täysin samaa mieltä. $23 \%$ vastaajista oli eri mieltä tai täysin eri mieltä.

Yksi kyselyn keskeisimmistä asioista oli tiivistetty kahteen viimeiseen väittämään. Ensimmäinen näistä oli väittämä "Tiedelehtien pitäisi siirtyä kohti avointa vertaisarviointia”. Tähän vastaajat ottivat kantaa hyvin erimielisesti: $37 \%$ oli samaa mieltä tai täysin samaa mieltä, $26 \%$ oli eri mieltä tai täysin eri mieltä, $37 \%$ ei samaa eikä eri mieltä tai en tiedä/en osaa vastata. Toinen kyselyn keskeinen väittämä oli "Kotimaisten tiedelehtien pitäisi toimia suunnannäyttäjinä siirtymisessä kohti avointa vertaisarviointia". Tähän väittämään osallistujat vastasivat miltei identtisesti edellisen yleisemmän väittämän kanssa: vastaukset olivat ristiriitaisia ja niiden joukossa oli suhteellisen suuri määrä neutraaleja tai epävarmoja mielipiteitä.
Tieteellisen kommunikaation kentästä yleisesti Mitä mieltä olet seuraavista väitteistä?

$$
0 \% \quad 20 \% \quad 40 \% \quad 60 \% \quad 80 \% \quad 100 \%
$$

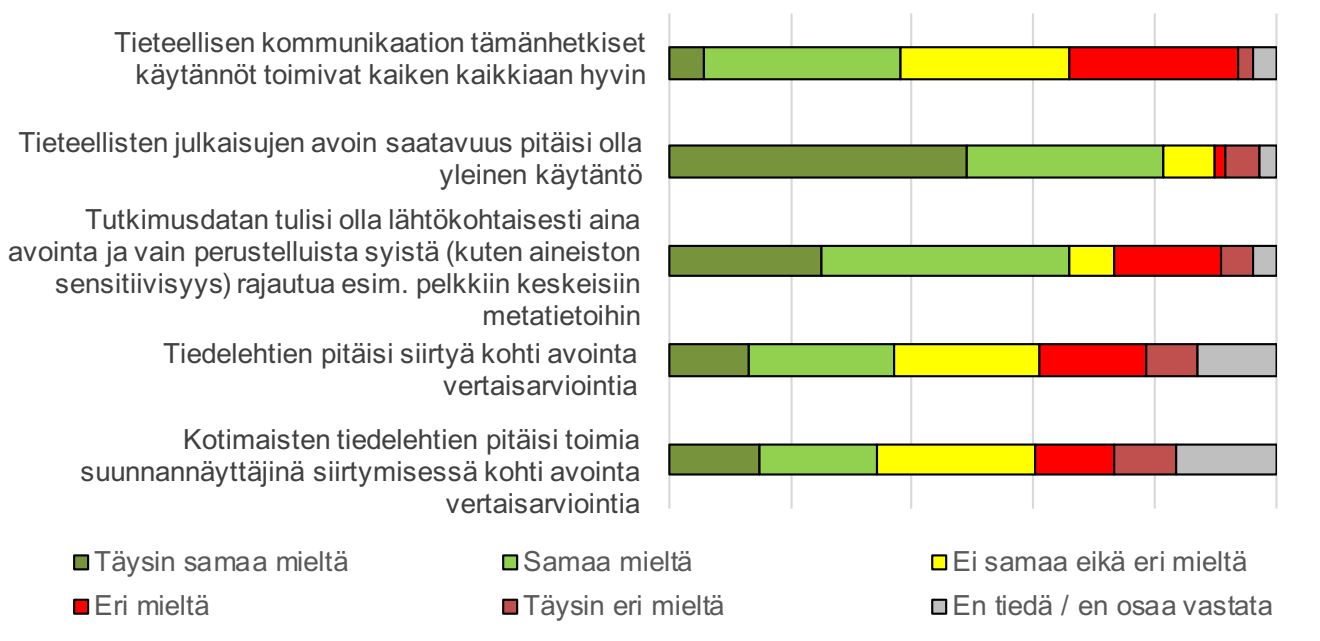

Kuva I 3 - Mielipiteitä tieteellisen kommunikaation kentästä yleisesti

\section{Vertaisarvioitujen kirjankustantajien haastattelut}

Lehtien ja kirjojen vertaisarvioprosessit eroavat toisistaan, minkä takia toteutimme myös haastattelun kotimaisille vertaisarviotunnusta käyttäville kirjankustantajille. Vertaisarviointitunnusta käyttäviä kirjankustantajia on Suomessa kymmenen:Aalto Arts Books, Eurooppalaisen filosofian seura (niin \& näin -kirjat), Gaudeamus, Vastapaino, Suomalaisen Kirjallisuuden Seura, Lapin yliopistokustannus, Tampere University Press, Into Kustannus, Tutkijaliitto sekä KehräMedia. Haastattelimme kaikkia kustantajia Kehrämediaa lukuun ottamatta. Saimme vastaukset kysymyksiimme kahdeksalta yhdeksästä kustantajasta. Haastatteluissa tavoitteemme oli saada syvennettyä ja täydennettyä kyselyssä esiin tulleita ilmiöitä, joten ne tukevat osaltaan kyselytulosten tulkintaa. Haastattelututkimuksen tavoite osana selvitystä oli antaa erityisesti kirjankustantajille mahdollisuus ilmaista näkökulmansa avointa vertaisarviointia koskeviin kysymyksiin. 
Haastattelut toteutettiin sähköpostihaastatteluina kesä-elokuussa 20I8, ja niihin pyydettiin vastaukset kunkin kustantajan kustannustoiminnasta vastaavalta päälliköltä tai henkilöiltä, jotka tuntevat kustantamon vertaisarvioprosessin parhaiten. Seuraavien yhdeksän kysymyksen avulla kartoitimme sitä, minkälaisista lähtökohdista kirjankustantajat lähestyvät vertaisarviointia:

I. Taustatietoja:Tämänhetkinen asemanne yrityksessä? Missä rooleissa olette toiminut tiedejulkaisemisen kentällä: kustantajana, toimittajana, kirjoittajana, vertaisarvioijana?

2. Minkälaisen vertaisarvioprosessin julkaistavaksi aiottu kirja käy läpi? Kuinka pitkä prosessi keskimäärin on?

3. Oletteko tyytyväinen tämänhetkiseen käytäntöön? Minkälaisia puutteita tai ongelmia siinä on?

4. Avoimeen vertaisarviointiin kuuluvat usein avoimet identiteetit $(=$ käytäntö, jossa kirjoittajan ja vertaisarvioijan henkilöllisyyksiä ei salata). Onko teillä kokemusta avoimista identiteeteistä? Miten henkilöllisyyden paljastaminen mielestänne vaikuttaisi vertaisarvioprosessiin?

5. Minkälaista hyötyä vertaisarviolausunnoista ja niiden sisältämästä tiedosta voi olla kustantajalle?

6. Avoimeen vertaisarviointiin kuuluvat usein avoimet lausunnot (= vertaisarviolausunnot julkaistaan artikkelin rinnalla). Olisiko vertaisarviolausuntojen julkaisemisesta hyötyä tai haittaa kustantajan näkökulmasta? Millaista?

7. Avoimeen vertaisarviointiin kuuluu usein avoin vuorovaikutus (= vertaisarviomenetelmä, joka sallii kirjoittajan ja vertaisarvioijan tai vertaisarvioijien välisen kommunikaation ja rohkaisee siihen). Mitä mieltä olette siitä, että vertaisarvioijat neuvottelisivat keskenään? Minkälaista hyötyä tai haittaa olisi siitä, että kirjan tai artikkelin kirjoittaja kommunikoisi suoraan vertaisarvioijan kanssa?

8. Miten suhtaudutte avoimeen vertaisarviointiin osana tämänhetkistä tendenssiä siirtyä kohti avointa julkaisemista? Minkälaisia muutoksia se tarkoittaisi kustantajan näkökulmasta?

9. Muita kommentteja (avoimeen) vertaisarviointiin liittyen.

\section{Prosessin kulku ja tyytyväisuus}

Kaikkien haastateltujen kustantamoiden julkaisuprosessi on pääpiirteittäin samanlainen: Saapunut käsikirjoitus ja sen soveltuvuus käydään ensin läpi toimituskunnan käsittelyssä, minkä jälkeen jatkoprosessiin hyväksytty käsikirjoitus lähtee vertaisarviointiin. Arviointiin kuluu aikaa keskimäärin I-3 kuukautta, mutta kaiken kaikkiaan prosessi käsikirjoituksen vastaanottamisesta kirjan julkaisuun vie huomattavasti enemmän aikaa. Tässä kohdin vastauksissa nousivat esiin myös kirjanjulkaisuprosessin erot suhteessa lehtien vertaisarviointiin: vielä enemmän työtä ja vielä hitaampi prosessi:

"Mutta kirjat (toisin kuin lehdet) on lähdetty taas rakentamaan alusta lähtien kokonaisuuksina, joten muutokset sisältöön ovat ongelmallisia: ne voivat vaatia muutoksia niin moneen osioon ja kokonaisuuden rakentamista uusiksi."

Tiedekirjojen vertaisarviointi on erilainen prosessi kuin lehtien, kun arvioitavana saattaa olla kokonainen kirja.Arvioinnista maksetaan toisinaan myös rahapalkkioita toisin kuin lehtiartikkelien vertaisarvioinnista.

"En usko että referee-lausunnon muuttaminen palkkiolliseksi on positiivinen signaali, koska kyse on kuitenkin tieteellisestä projektista jonka pitäisi olla intressivapaata eli se kuuluu tutkijan työhön tieteellisessä kommunismissa. Nyt kustantamon puolella maksamme palkkion välillä sellaiselle, joka ei toimi Suomessa tai yliopistolla palkallisessa tehtävässä."

Vertaisarviointi pitäisikin nähdä tutkijan meritoitumisena ja ansiona, joka ei ole vain pois hänen työajastaan.

Eroja työmäärien välillä tuottavat myös monografian ja artikkelikokoelman formaatit. Esimerkiksi monitieteisessä artikkelikokoelmassa saatetaan joutua etsimään jokaiselle artikkelille oma arvioijansa, ja monografiaprosessia hidastaa yhden vertaisarvioijan osaksi koituva suuri työmäärä. Vertaisarvioinnin merkitys korostuu siis entisestään monitieteisten julkaisujen kohdalla, ja monitieteisyys asettaa omat haasteensa asiantuntevan vertaisarvioijan löytämiselle.

Suurin osa kustantajista oli melko tyytyväisiä tai tyytyväisiä vallitsevaan vertaisarviokäytäntöön. Tärkeänä pidettiin sitä, että kustantajat voivat itse vaikuttaa vertaisar- 
violausuntojen laatuun ohjeistamalla arvioijia riittävästi, mikä korostaa kustantajan vastuullisuutta.Vastauksissa näkyy myös se, kuinka suuri merkitys Tieteellisten seurain valtuuskunnan lanseeraamalla vertaisarviointitunnuksella on ollut käytäntöjen yhdenmukaistamisessa.Vertaisarviotunnuksen käyttöön viitattiin laadun takeena.

Tämänhetkiseen vertaisarviointiin liittyvät puutteet ovat linjassa kansainvälisessä keskustelussa esiin tulleiden ongelmien kanssa. Hankalinta on vaikeus löytää sopivia vertaisarvioijia, ja syitä tähän on useita: tutkijat ovat ylityöllistettyjä eikä vertaisarviointi meritoi riittävästi. Lisäksi julkaistavat sisällöt saattavat olla kapeille kohderyhmille suunnattuja, mikä vielä lisää vaikeutta löytää arvioijia. Myös satunnaiset huonosti laaditut lausunnot sekä vertaisarvioijien lausuntojen keskinäinen yhteismitattomuus tai ristiriitaisuus haittaavat toisinaan prosessin jouhevaa kulkua. Muutama vastaaja mainitsee vielä erikseen prosessin hitauden, mikä johtuu juuri edellä mainituista ongelmista.

\section{Anonyymiys herättää ajatuksia}

Kustantamoissa noudatetaan yleisesti kaksoissokkovertaisarviointia, vaikkakaan aivan kaikki vastaajat eivät spesifioineet tätä.Yhdessä kustantamossa käytettiin puoliavointa vertaisarviointia, jossa arvioijat tietävät kirjoittajan henkilölisyyden, mutta kirjoittaja ei tiedä arvioijien henkilöllisyyttä. Kustantajat ovat käyttäneet aikaa parhaan mahdollisen vertaisarviointikäytännön pohtimiseen:

"Olenkin usein pohtinut, olisiko single blind -käytäntö rehellisempi ja parempi, siis sellainen, että kirjoittajan nimeä ei yritetä anonymisoida tekstistä mutta arvioijien nimiä ei paljasteta kirjoittajalle. Olisiko sekään sitten toisaalta reilua, siinäpä kysymys. Eihän periaatteessa ole tasapuolista, että toisen osapuolen nimi paljastetaan mutta toisen ei. Mutta käytännössä voi olla, että silloin arvioijat uskaltavat esittää kriittisiäkin kommentteja, vaikka kirjoittaja olisikin arvovaltaisempi henkilö kuin arvioija."

"Itse suhtauduin anonymiteettiin (tuplasokkoon) alun perin hieman kriittisesti, mutta nyt olen huomannut, että se tuottaa hyvää varovaisuutta, jossa ad hominem -argumentti ei ole käytettävissä, vaikka usein arvioitsijalla on arvauksia tekijästä. On arviointiteknisesti arvokasta, että joutuu käyttämään ainoastaan materiaalina sitä mitä käsikirjoituksessa on eikä edes ohjaavana mielikuvana argumentaatiolle sitä, mitä oikeaan tekijään liitetään. Lisäksi tieteellistä keskustelua käydään ennen julkaisemista ja mutta myös ja etenkin julkaisemisen jälkeen - esimerkiksi kirja-arvioina ja julkisena väittelynä."

Suomen kokoisessa maassa ja pienistä piireistä koostuvassa tiedeyhteisössä anonyymiys voi jo tällä hetkellä olla näennäistä, mikä vastauksista myös tulee ilmi. Toisaalta todetaan, että vaikka identiteettien avaaminen eittämättä yksinkertaistaisi prosessia, anonymisointi ei aina syystä tai toisesta onnistu. Muutama kustantaja on sitä mieltä, että nimien julkistaminen vaikeuttaisi arvioijien löytymistä. Kenties anoyymiys mahdollistaa paremmin kriittisyyden. Identiteettien avaamiseen liittyviä hyötyjä kuitenkin punnitaan: Jos identiteetit olisivat avoimet, vertaisarvioija voisi lisätä tehdyn työn ansioluetteloonsa. Nyt lausunto jää kokonaan näkymättömäksi tai ainakin jää kohdentamalla, mihin käsikirjoitukseen arvioija on antamallaan lausunnolla kontribuoinut.

Erilaisista vertaisarviointiin liittyvistä valtasuhteista esiin tulee toistuvasti akateeminen status ja sen vaikutus prosessiin. Esimerkiksi annetaan usein tilanne, jossa arvioitava on tunnettu professori ja arvioija taas on nuorempi tutkija. Sen sijaan erilaisten sukupuoleen, taustaorganisaatioon tai maantieteelliseen sijaintiin liittyvien vinoumien merkitys anonymisoinnista päätettäessä ei juurikaan näy vastauksissa.Yksi kustantaja nostaa esiin tärkeän kysymyksen tiedekulttuurien ja tutkimusaiheiden välisistä eroista ja niiden vaikutuksista henkilöllisyyden paljastamiseen.

"Jotkut alat esim. nostavat enemmän mm. vihapuhetta, jolloin tutkijat ovat tiedostavampia nimen esiintymisestä."

Täysin avoimesta arvioinnista pohdiskelun tueksi otetaan esimerkki väitöskirjojen arvioinnista, jossa henkilöllisyyksiä ei missään vaiheessa salata.Väitöskirjaprosessin ero muuhun julkaisutoimintaan on kuitenkin siinä, että väitöskirjaprosessissa ei edes väitetä arvioijan olevan vertainen. Kysymys hierarkiasta on akateemisessa maailmassa ja sitä myöten myös vertaisarvioprosessissa keskeinen. Yleisemmin voidaankin pohtia sitä, kuinka usein prosessi ylipäätään on tai sen kuuluu olla vertaisten välinen ja kuinka usein arviointi on etabloituneemman tutkijan antamaa opastusta vähemmän kokeneelle kollegalle. 
Monissa vastauksissa toistuu huoli avoimen vertaisarvioinnin mukanaan tuomasta todennäköisesti lisääntyvästä työtaakasta:

”Jos prosessi muutettaisiin avoimeksi, se tarkoittaa, että arvioitsijan pitäisi muotoilla kritiikki myös julkisuutta varten, koska hän vastaa siitä omalla nimellään. Tämä taas tarkoittaa lisää työtä ja suoraan intressien avaamista arvioitavan ja arvioitsijan nykyisiin ja tuleviin projekteihin. Tämä on erityisen ongelmallista suomenkielisen julkaisemisen piirissä, koska piirit ovat pienet. Mitä sanoo julkisesti ja mitä ei?"

"Henkilöllisyyden paljastaminen tai salaaminen ei ole yksiselitteisesti ainoastaan hyvä tai huono asia, mutta avoimuudessa ja sen yleistymisessä olisi kyllä mielestäni hyötyjä. Pidän avoimen vertaisarvioinnin edelleen lisäämistä vakavan harkinnan ja keskustelun arvoisena."

Henkilöllisyyteen liittyvät kysymykset ovat monin tavoin ongelmallisia ja kantavat mukanaan erilaisten seurauksien vyyhtiä.Vastauksissa ei olekaan näkyvissä minkäänlaista yhdenmukaisuutta identiteettien paljastamisen tai salaamisen suhteen.

\section{Avoimet lausunnot eivät houkuttele}

Suurin osa haastatelluista kustantamoista ei nojaa avoimeen julkaisutoimintaan avoimen saatavuuden (open access) periaatteella, mikä näkyy myös vastauksissa. Erityisesti tämä tulee esiin avoimia lausuntoja koskevan kysymyksen kohdalla. Lausuntojen merkitys kustantajalle sinänsä on selvä: lausunnot sisältävät kustantajan kannalta paljon tärkeää tietoa.

"Tiedekustantajalle lausunnot ovat ratkaisevan tärkeitä, sillä toimituksella ei voi olla riittävää asiantuntemusta kaikkien tutkimusalojen sisällön arviointiin."

"Vertaisarviointilausunnot voivat myös auttaa kustantajaa sen selvittämisessä, onko käsikirjoituksessa olennaista uutta tietoa vai onko sen uutuusarvo vähäinen (esim. samasta aiheesta on jo olemassa erinomainen teos, johon nähden käsikirjoitus ei tuo juuri uutta). Samoin vertaisarvioijat pohtivat parhaimmillaan sitä, olisiko kirjalla käyttöä esim. oppikirjana tai mitä muuta käyttöä sillä voisi olla - joskus valitettavasti vertaisarvioijien johtopäätöksenä voi olla, että kirjalla ei juuri olisi käyttöä eikä lukijoita. Toisaalta joskus vertaisarvioijat voivat tuoda esille sellaisia kohdeyleisöjä tai kirjan käyttömahdollisuuksia, joita kustantaja ei itse olisi tullut ajatelleeksi."

Vertaisarviolausunnot myös osaltaan valmistavat kustantajaa siihen, minkälaista palautetta julkaisemisen jälkeen on tulossa. Lausuntoja ja käsikirjoitusversioita myös tallennetaan tutkimuseettisistä syistä.

Lausuntojen avaaminen osana avointa vertaisarviointia on kustantajille suhteellisen vieras ilmiö, josta ei ole juuri kokemusta. Avoimia lausuntoja kustantajat pitävät pääsääntöisesti itselleen vieraana ja myös jokseenkin epärelevanttina. Lausuntojen julkaiseminen saattaa olla suorastaan absurdi ajatus: "Kirjoittaja kirjoittajana ja lausunnoija lausunnoijana." Avoimiin lausuntoihin liittyi paljon epäselvyyksiä, mikä osaltaan kertoo ilmiön vakiintumattomuudesta suomalaisella tiedekentällä. Selvää ei ole, mikä kaikki materiaali on lausuntoon kuuluvaa. Rajankäynti julkaistavan artikkelin ja siihen kytkeytyvien muiden tekstien, kuten vertaisarviolausuntojen ja kustannustoimittajien kommenttien välillä voi muuttua epäselväksi. Lausuntojen julkaiseminen voi johtaa siihen, että niitäkin aletaan viimeistellä enemmän julkaisua muistuttaviksi ja niihin aletaan kohdistaa myös paineita samalla tavalla kuin julkaistavaan artikkeliin. Entä julkaistaisiinko kaikki lausunnon sisältämä informaatiosisältö, esimerkiksi kieleen ja tyylillisiin seikkoihin liittyvät korjaukset?

"Miksi kirjassa pitäisi olla arvio siitä, millainen käsikirjoitus oli alustavassa vaiheessaan, kun virheet on lopulliseen julkaisuun korjattu? Kustantajan kannalta haitta olisi siinä, että lukijan kannalta arviot olisivat usein epärelevantteja.Arviointien julkaiseminen soveltuu mielestäni vain järjestelmään, jossa käsikirjoitukset julkaistaan jotakuinkin sellaisenaan ja arviot silloin vastaavat normaalia kirja-arvostelua."

Lausuntojen julkaisemiseen liittyvä työn lisääntyminen tulee esiin useammassa vastauksessa:

"Lausuntojen julkaiseminen tietäisi lisätyötä: niiden pitäisi olla kenties muodoltaan standardisoidumpia, ja niillä pitäisi olla jokin julkaisualusta. Lausuntojen julkaiseminen voisi hankaloittaa arvioijien löytämistä ja 
lisätä kustantajaan kohdistuvaa julkista kritiikkiä, jos kirjoittajat eivät olekaan syystä tai toisesta tehneet arvioitsijan vaatimia muutoksia."

Kuitenkin lausuntojen avoimuudessa nähdään huonojen puolien ohella jotain hyvääkin, nimittäin tietoisuus siitä, minkälaisia prosesseja tekstin käyvät läpi:

"Jos kustantaja ottaisi linjan, että vertaisarvioinnit julkaistaan, se voisi karkottaa potentiaalisia kirjoittajia ja arvioijia, jos he eivät halua arvioiden tulevan julkisiksi. Hyötynä toisaalta olisi avoimuus: prosessi olisi läpinäkyvä. Se myös voisi kasvattaa tietoisuutta siitä, että kirjoittaminen on prosessi eivätkä tekstit ole koskaan heti valmiita vaan niiden eteen tehdään paljon työtä ja niitä muokataan kirjoitus- ja editointiprosessin aikana paljon. Tosin seuraava kysymys on sitten, että pitäisikö myös kustannustoimittajan tai lehden toimittajan kommentit julkistaa? Toimittajakin tekee paljon työtä tekstin parantamiseksi.”

Jo aiemmin on tullut esiin se keskeinen seikka, että avoin julkaiseminen ja avoin vertaisarviointi kulkevat yleensä käsikkäin. Toistaiseksi on harvinaista, että tilauspohjainen lehti ottaa käyttöönsä avoimen vertaisarvioinnin käytäntöjä. Seuraavissa kommenteissa avoimen vertaisarvioinnin luja kytkös avoimeen julkaisemiseen korostuu:

”Avoimet arviot voisivat toimia sellaisessa sähköisessä julkaisemisessa, jossa tutkimusta tai tekstejä myös jatkotyöstettäisiin joko kirjoittajien omalla panoksella, keskustelun tai avoimen yhteiskirjoittajuuden muodossa."

”Avointa vertaisarviointia olisi luontevampaa kokeilla sähköisessä julkaisuympäristössä - varsinkin sellaisessa, jossa tutkimusta tai tekstejä jollain tapaa jatkojalostettaisiin senkin jälkeen, kun vertaisarviointi on asetettu julkisesti nähtäville.Aikakauslehtityyppistä formaattia olisi ehkä helpompi kehittãä tähän suuntaan kuin kirjajulkaisemista."

Tällöinkin avoimeen julkaisemiseen siirtymisen käytännön edellytykset ja niiden huomioon ottaminen on oleellista:

"Sähköisen vertaisarviointialusta, johon tekijät itse "submittaavat" käsikirjoituksensa, olisi toimivan avoimen vertaisarvioinnin edellytys. Siihen siirtyminen on iso kynnys kustantajalle, sillä alustan on oltava ehdottoman varmatoimintoinen ja helppokäyttöinen.”

\section{Avoin vuorovaikutus - tilanne ratkaisee}

Avoimen vertaisarvioinnin yhtenä asteena pidetään avointa vuorovaikutusta, joka sallii kirjoittajan ja vertaisarvioijan tai vertaisarvioijien välisen kommunikaation ja rohkaisee siihen. Haastattelujen perusteella suomalaisen tiedejulkaisemisen kentällä tällaisesta ei juuri ole kokemusta muutamaa poikkeusta lukuun ottamatta. Muutamassa erillistapauksessa on päätetty, että "kustantamo voi pyytää vertaisarvioijalta luvan paljastaa tämän identiteetti tekijälle, jotta he voivat käydä substanssikeskustelua käsikirjoituksesta." Myös jos arviointikierroksia on useampia, lausuntoja voidaan avata: "Toisen ja sen jälkeisten arviointikierrosten yhteydessä käytetään yleensä yhtä arvioijaa, joka näkee myös aiemmat lausunnot."

Ajatus avoimesta vuorovaikutuksesta kirvoittaa kustantajilta runsaasti pohdiskeluja ja näkemyksiä, joissa konteksti otetaan huomioon ratkaisevana tekijänä:

"Silloin kun käsikirjoitus on hyvä, avoin vuoropuhelu nähdäkseni toimisi."

"Riippuu mielestäni todella paljon käsikirjoituksesta, kirjoittajasta ja arvioijista, milloin avoimesta vuorovaikutuksesta on hyötyä ja milloin haittaa. Kyse on tiimityöstä ja kommunikaatiosta, jonka tulee toimia hyvin, jotta päämäärä eli tieteellisesti laadukas käsikirjoitus saavutetaan.”

"Arvioijien sekä kirjoittajien ja arvioijien välinen suora kommunikaatio todennäköisesti parantaisi vertaisarvioinnin laatua. Arvioijat voisivat oppia toisiltaan, mahdolliset jyrkät näkemyserot voisivat lieventyä ja samalla he kenties loisivat uusia yhteistyökuvioita.Arvioijat pystyisivät perustelemaan näkemyksiään kirjoittajille ja kirjoittajat kysymään neuvoa.Tällöin palaute olisi dialogisempaa ja ohjaavampaa.Arvioija olisi todellakin kirjoittajan vertainen (peer) eikä tuomari (referee)."

"Tässäkin vaikuttaa valtasuhde. Kumpi on kokeneempi? Voisin kuvitella olevan kiusallista, jos toinen on vasta väitellyt ja toinen professoristason kirjoittaja - ei siksi, että asiantuntemuksellisuutta kyseenalaistaisin. Osaaminen ei ole tittelistä eikä edes työvuosista kiinni, mutta vertaisarvioinnissa tulisi olla tasavahvat toimijat osapuolina. Mutta sitten taas 
Suomen markkinoilla kysymys voikin olla siitä, että onko osapuolilla liian todennäköisesti yhteistä historiaa liikaa, mikä taas tekee osapuolista puolueelliset?"

Läpinäkyvyyteen pyrkivän vuorovaikutuksen nähdään tuovan paljon mahdollisuuksia vertaisarviointiin, mutta toisaalta dialogisuuden ongelmaksi voi nousta liiallinen konsensus ja toisten kommenttien myötäily. Näkemyserot suhteessa avoimeen vuorovaikutukseen ovat osin jyrkkiäkin. Ajatus avoimesta vuorovaikutuksesta myös tyrmätään kokonaan, kun yksi vastaajista muistuttaa vertaisarviointiprosessin merkityksen piilevän juuri riippumattomuuden takaavassa vertaisarvioijan ulkopuolisuudessa: "Ateljeekritiikkiä on jo olemassa, ja vertaisarviointiprosessissahan tarkoituksena on nimenomaan esittää ulkopuolinen tieteellinen näkökulma."

Myös kustantajan keskeinen rooli prosessissa korostuu.Vaikka kirjoittaja ja vertaisarvioija kommunikoisivat suoraan keskenään, kustantajan täytyisi pysyä prosessissa mukana:

"Vaikka arvioijat ovat julkaisujen aiheiden parhaita asiantuntijoita, kustantajan edustajat ovat kustannusalan parhaita asiantuntijoita.Vaikka kustantajalla ei toki ole mitään syytä puuttua julkaisuprosessin tieteellisten käytäntöjen ja vaatimusten toteutumiseen, julkaisujen editoinnissa on silti syytä pitää huolta myös kustantajan vahvuuksiin kuuluvista tekijöistä. Kustantaja voi omalla osaamisellaan parantaa julkaisujen vaikuttavuutta varmistamalla, että vertaisarvioidutkin julkaisut olisivat mahdollisimman hyvin hyödynnettävissä myös tiedeyhteisön ulkopuolella tieteellisen validiteetin kärsimättä.Toisaalta kirjoittajan ja arvioijan suora keskinäinen kommunikaatio voisi myös vähentää kustantajan työmäärää, kun kustantajan edustajan ei olisi pakko välittää kaikkea kommunikaatiota."

"Kritiikin saaminen omasta tekstistä on herkkä paikka, ja vaikka kirjoittajat ovat yhä paremmin tottuneet vertaisarviointikäytänteisiin ja suurin osa suhtautuu niihin korrektisti, ottaa osa kirjoittajista edelleen puolustusasenteen suhteessa arviointilausuntoon. Jos arvioija ja kirjoittaja olisivat tällaisessa tapauksessa suoraan tekemisissä keskenään, olisi konfliktin vaara ilmeinen, ja arvioijia olisi entistä vaikeampi saada. Jos taas esimerkiksi koulukuntaerojen vuoksi kirjoittajan ja arvioijan näkemykset poikkeavat jyrkästi toisistaan, voisi suora keskinäinen kontakti johtaa konfliktiin. Toivottavinta kontakti olisi silloin, kun arvioijalla selvästikin on sellaista tutkimusta tai tekstiä koskevaa tietoa (esim. tutkimuslähteitä), joissa hän voisi neuvoa kirjoittajaa ja joissa pelkkä lähdeviite ei tunnu riittävän. Joskus arvioija ei asetu ymmärtämään kirjoittajan lähtökohtia ja rajausta vaan esittää muokkaustoiveita aivan eri lähtökohdista."

Tällöinkään suora kontakti ei haastateltavan mukaan välttämättä ratkaisisi tilannetta vaan toimittajan rooli vastuu- ja kontaktihenkilönä korostuu. Toimittajan rooli on keskeinen siinä, minkälaisia ratkaisuja vertaisarvioinnin suhteen tehdään ja mitkä toimintatavat muodostuvat hyväksyttäviksi vertaisarvioinnin suhteen.

Kustantajista muutamat ovat tehneet avoimuuteen ja sen eri asteisiin liittyviä kokeiluja, ja heidän kokemuksensa mukaan vertaisarvioijat pyrkivät avoimuudesta huolimatta aidosti parantamaan käsikirjoitusta. Avoimuutta ja läpinäkyvyyttä lisäävänä käytäntönä eräs kustantamo lähettää prosessin päätteeksi kaikille asianosaisille prosessia avaavan kirjeen:

"Lähetämme julkaisuprosessin päätteeksi kiitoskirjeen eri sidosryhmille, jossa pyrimme vertaisarvioijille avaamaan prosessia - ja sitä mitä käsikirjoitukselle on matkanvarrella tapahtunut, mitä huomioitu. Eli haluamme avata tätä ainakin niille, jotka täysin ulkopuolisena ovat antaneet työpanostaan maksutta meille."

Yksi kustantaja mainitsee tuntevansa uusimmat innovaatiot, kuten joukkoistetun vertaisarvioinnin tai julkaisemisen jälkeen tapahtuvan vertaisarvioinnin. Muutosten kannattavuutta on kuitenkin hartaasti punnittava:

"Kustantajalle uudet arviointimuodot tarkoittavat muutoksia ja lisätyötä, joten on pohdittava tarkkaan, mitä lisäarvoa avoin vertaisarviointi voi tuoda kustantajalle." 


\section{Kaikki vaikuttaa kaikkeen}

Haastattelujen perusteella kotimaiset kirjankustantajat ovat hyvin selvillä kansainvälisellä kentällä tapahtuvista muutoksista ja ovat kiinnostuneita ja halukkaita saamaan lisää tietoa vertaisarvioinnin muuttuvista käytännöistä. Kustantajat näyttävätkin pääsääntöisesti olevan odottavalla kannalla: uudet käytännöt kiinnostavat, mutta tietoa ja kokemusta pitäisi saada lisää.

"Suhtaudun asiaan siten, että asiassa kannattaa edetä harkitusti ja varovaisesti. Kirjoissa en vielä siirtyisi avoimeen vertaisarviointiin. Avointa vertaisarviointia kannattaa ensin kokeilla lehdissä ja siitä on syytä hankkia paljon kokemusta ja tätä kokemusta on syytä analysoida ja tutkia huolellisesti. Sen jälkeen on helpompi pohtia asiaa lisää ja miettiä, voisiko kirjoissakin ottaa käyttöön näitä käytäntöjä.”

"Ajattelutapa ja -kulttuuri vaatisi päivittämistä, mutten vastusta ajatusta. Jos yleisesti siirrytään avoimeen vertaisarviointiin, ja menetelmä riskeineen ja menettelyineen tulee tutuksi ja vakiintuneeksi, niin silloin omaksuminen on helpompaa ja jouhevampaa."

Avoimuuteen siirtymisen erilaisiin riskeihin ja kentältä tulevaan vastaanottoon kiinnitetään huomiota:

"Pienenä kustantajana, jonka resurssit ovat pienet, ei kuitenkaan välttämättä haluaisi olla se ensimmäinen, joka ottaa maassa kritiikin ja arvostelun vastaan."

Yksi keskeinen riskeihin liittyvä kipukohta on avoimuuden rahoittaminen:

"Avoin julkaiseminen on tietysti hyvä asia tieteen kannalta. Kustantajan näkökulmasta vastaan tulevat kustannukset: kuka maksaa julkaisun tuotantoprosessiin liittyvät kustannukset, jos itse julkaisusta ei voida veloittaa?"
"Kaupallisen yleiskustantamon näkökulmasta avoin julkaiseminen vaatisi ensisijaisesti uudenlaista rahoituspohjaa, jolla julkaisemisen kulut voitaisiin kattaa. Teknisiä esteitä avoimelle julkaisemiselle ei sinänsä ole olemassa."

"Minulle sopisi hyvin kirjojen kustantamisessa kommunistinen malli, jossa valtio maksaisi kustantajalle kirjojen tekemisestä. Koska toistaiseksi tästä ei ole toiveita, toivoisin, että suomenkielisen korkeatasoisen tieteellisen kirjallisuuden ja tietokirjojen julkaisemista ei tuhottaisi avoimeen tieteeseen vetoamalla. Näyttää siltä, että avoin julkaiseminen saa tukirahoitusta kun taas kaupallinen kustantaminen ei tukea juurikaan saa."

Kriittiset kommentit koskevat ylipäätään julkaisemisen ylikorostumista tämänhetkisessä tulosohjauksen ajan yliopistossa:

"Minusta keskustelu avoimesta julkaisemisesta ylikorostuu siksi, että yliopistoissa tutkimusta ja toimintaa arvioidaan liikaa julkaisupainotteisesti. Opetus-, ohjaus-, sivistystyönmerkitys yliopistossa on vähentynyt. Siksi ymmärrän että halu tarttua julkaisemisen prosessiin ylikorostuu myös, koska julkaisemiselle on ylipäätään annettu liian suuri arvo. Luulisi että Wikileaksilta olisi opittu, että kaiken muuttaminen julkiseksi ja avoimeksi ei tuota parempaa maailmaa ja parempia käytäntöjä, vaikka avoimuudesta onkin tiettyyn rajaan asti hyötyä - etenkin jos oikeaa tietoa ei ole ollenkaan saatavilla."

Kansainvälisen ja kansallisen väliset erot julkaisutoiminnassa otetaan toki huomioon:

"Itse olen toiminut journalistina kyllä avoimen julkaisemisen ja lähdekoodin puolesta kun vastassa ovat suuret kansainväliset yritykset, mutta keskustelu on erilainen erityisesti yliopistomaailmassa riippuen siitä, puhutaanko suurista kansainvälisistä kustantajista vai suomalaisista."

Myös itse avoimuuden käsite herättää pohdintoja ja se määritellään laajasti:

"avoin tiede ja avoin julkaiseminen ovat tärkeitä asioita. Ne eivät kuitenkaan tarkoita samaa.Avoimen tieteen osuutta olisi mielestäni järkevä painottaa - siis oikean tieteellisen keskustelun käymistä." 
Avoimen julkaisemisen yleisenä linjana painotetaan kirjastojen yleisen palvelun merkitystä:

"Sitä että suomenkielinen monografia on saatavissa tieteellisestä ja julkisesta kirjastosta.Tämä pitäisi nähdä myös avoimena julkaisemisena, koska kaikki jotka osaavat lukea suomea osaavat myös käyttää kirjastoa. Kirjasto takaa taas kirjoittajalle ja kustantajalle mallin jolle on olemassa infrastruktuuri, luokittelu ja rahoitus. Kaupalliselle kustantajalle suomenkielisten tekstien laittaminen rinnakkaistallennerekisteriin tuottaa vaikean tilanteen taloudellisesti, koska taloudelliselle menetykselle ei ole korvaavaa rahoitusta."

Mitään selkeää, yksiäänistä vastausta kustantajilta ei kuulu avoimen vertaisarvioinnin suhteen. Jotkut ovat ehdottoman anonymiteetin kannalla, toiset innokkaampia kokeilemaan uusia toimintamuotoja.

Teknologia on mahdollistanut avoimen vertaisarvioinnin jo kauan. Tiede on ihmisten tekoa ja sellaisena sosiaalista toimintaa, joten on olennaista, miten tutkijat, kustantajat ja julkaisijat itse suhtautuvat erilaisiin vertaisarvioinnin tapoihin. Kustantajat ajattelevat, että tärkeämpää kuin kustantajan kertakaikkinen kanta asiaan onkin yhteisymmärrys tutkimuksen kirjoittajan kanssa: se minkälaiseksi julkaisuprosessi muodostuu, voitaisiin sopia ja neuvotella yhdessä kirjoittajan kanssa kustantajan tekemän yksipuolisen päätöksen sijaan. Kustantajien vastauksissa korostuukin kaikkein tärkeimpänä seikkana tilannekeskeisyys, sillä huomioon otettavia seikkoja on lukuisia. Eräs kustantaja kiteyttääkin erinomaisesti myös tässä raportissa korostuvan ajatuksen avoimuudesta ennemminkin asteittaisena spektrinä kuin kertakaikkisena valintakysymyksenä:

"Kaikki vaikuttaa kaikkeen, joten avoin vertaisarviointi ei ole "kyllä/ ei”-kysymys."

\section{Yhteenveto: avoin vertaisarviointi - hyötyjen ja haasteiden tasapainottelua}

Selvitystyön tavoitteena oli herättää keskustelua vertaisarvioinnista tiedejulkaisemisen yhtenä keskeisenä tekijänä ja ottaa selvää, kiinnostaako teema ylipäätään kotimaisia lehtiä ja kirjankustantajia. Tunnetaanko avoimen vertaisarvioinnin periaatteet? Selvityksen tarkoitus ei ole määritellä ulkoapäin kullekin lehdelle sopivia toimintatapoja tai lisätä julkaisuprosessin byrokraattisuutta. Sen sijaan eetoksena on lisätä ymmärrystä vertaisarvioinnin eri keinoista ja käytännöistä erityisesti suhteessa tieteen avoimuuteen. Selvitystyön tavoitteena ei ollut suoranaisesti antaa suosituksia tai ottaa kantaa vertaisarviointiin vaan selvittää nykykäytäntöjä sekä tutkijoiden, vertaisarvioijien ja julkaisijoiden asenteita vertaisarviointia kohtaan.

Sekä kyselyn että haastattelujen perusteella tyytyväisyyden aste vallitsevaan vertaisarviojärjestelmään on korkea. Mitään vahvaa trendiä ei kuitenkaan ole löydettävissä, ennemminkin esiin nousee suhteellisen pirstaleinen, laaja kirjo näkemyksiä ilmiön eri puolista. Kyselyn tuloksista nousi esiin monia ristiriitaisuuksia, jotka vaativat lehdiltä tasapainottelua sen suhteen, minkälaisia valintoja avoimuuden suhteen ne tekevät.

Suurin osa vastaajista oli sitä mieltä, että avoimet vertaisarviolausunnot ja avoimet identiteetit parantaisivat lausuntojen laatua. Toisaalta kuitenkin arvioijien rekrytoinnin arveltiin vaikeutuvan, mikäli lausunto julkaistaan avoimesti itse artikkelin rinnalla. Lehden toimituskunta joutuu siis punnitsemaan valintojaan tietynlaisessa ristipaineessa. Tuloksista ilmeni lisäksi, että avoimuuden nähtiin vaikuttavan myös itse arvion sisältöön. Lausuntoa kirjoittava vertaisarvioija saattaa esimerkiksi vältellä kriittisimpiä näkemyksiään välttääkseen mahdollisia ristiriitatilanteita.

Vertaisarviointi ja sen avoimuus kirjankustannustoiminnassa havaittiin monin tavoin erilaiseksi prosessiksi kuin tieteellisissä lehdissä. Eroja on rahoituspohjan lisäksi myös muun muassa avoimen julkaisemisen kehityksen eritahtisuudessa: kirjojen kohdalla avoin julkaiseminen ei ole edennyt samassa rintamassa lehtien kanssa, eikä avointa vertaisarviointia voida kovinkaan helposti toteuttaa ilman avoimeen julkaisemiseen siirtymistä. 
Avointa julkaisemista on monessa yhteydessä edistetty erilaisilla pakotteilla ja vahvoilla kannustimilla. Päätelmämme kerätyn aineiston pohjalta on, että tällaiset yksinkertaiset ja hyvin yleisellä tasolla tehtävät linjaukset eivät sovellu kovinkaan hyvin avoimen vertaisarvioinnin edistämiseen. Parasta olisi, jos kukin lehti ja kustantaja arvioisi omista lähtökohdistaan sekä lehden erityisten intressien kannalta, mitkä avoimen vertaisarvioinnin osa-alueista olisi kannattavaa ottaa käyttöön.

Tärkeää on asettaa tulokset mittasuhteisiinsa.Varsinkin kyselyn tuloksia tulkittaessa huomion arvoista on sen pieni otos. Kirjojen osalta tilanne on sinänsä kattava, että haastatteluihin osallistuivat lähes kaikki Suomen vertaisarviotunnusta käyttävät kirjankustantajat. Kuitenkin on huomattava eri tieteenalojen julkaisukulttuurien väliset erot: kirjoina julkaisemisen merkitys vaihtelee tieteenaloittain, ja Suomessa paino on yhteiskunta- ja humanistisissa tieteissä. Kysely ja haastattelut toimivat työkaluina avointa vertaisarviointia koskevia tulevia selvityksiä varten.

\section{Lähteet}

Allardt, E. (2002). Tiedeyhteisö ja vallankäyttö. Sakari Karjalainen \& Veikko Launis \& Risto Pelkonen \& Juhani Pietarinen (toim.): Tutkijan eettiset valinnat. Helsinki: Gaudeamus, 299-3। 5.

Bartling, S., \& Friesike, S. (20I4). Towards Another Scientific Revolution. In S. Bartling \& S. Friesike (Eds.), Opening Science:The Evolving Guide on How the Internet is Changing Research, Collaboration and Scholarly Publishing (pp. 3-15). Cham: Springer International Publishing. https://doi.org/I0.1007/978-3-319-00026-8_I

Binswanger, M. (2014). Excellence by Nonsense. Opening Science. The Evolving Guide on How the Internet is Changing Research, Collaboration and Scholarly Publishing. Springer Open, 49-72. https://doi.org/ 10.1007/978-3-319-00026-8

Bornmann L., Daniel, H-D. (2010). Do Author-Suggested Reviewers Rate Submissions More Favorably Than Editor-Suggested Reviewers? A Study on Atmospheric Chemistry and Physics. PLoS One 5 (10), el 3345. https://doi.org/10.137//journal.pone.0013345

Casnici, N., Grimaldo, F., Gilbert, N., Squazzoni F. (2017). Attitudes of Referees in a Multidisciplinary Journal:An Empirical Analysis. Journal of the Association for Information Science and Technology 68 (7), I763-I77I. https://doi.org/I0.1002/asi.23665

Görögh, E., et al (2017). Deliverable D3.I- Practices, evaluation and mapping: Methods, tools and user needs. OPENing UP new methods, indicators and tools for peer review, impact measurement and dissemination of research results. http://openup-h2020.eu/wp-content/ uploads/2017/0I/OpenUP_D3.I_Peer-review-landscape-report.pdf

Hallamaa, J. (2002). Kuka valvoo tiedettä. Tieteessä tapahtuu 20 (I), 3-5. https://journal.fi/tt/ article/view/57479

Hellman, H. \& Poteri, E. (20I2). Kotimainen julkaisutoiminta uuden rahoitusmallin ja Julkaisufoorumin jälkeen. Media \& Viestintä 35 (3-4), 6-19. https://journal.fi/mediaviestinta/article/ view/62877

Heinonen,A. \& Raevaara,T. (20I2). Yliopistojen kolmas tehtävä jää vaille toteutusta ja tukea. Tieteessä tapahtuu 30(5), 3-8. https://journal.fi/tt/article/view/6875 
Ikonen, R. (20 I8). Avoimen julkaisemisen jättiaskel. Tieteessä tapahtuu 36 (5), 33-4I. https:// journal.fi/tt/article/view/75093

Ilva, J. \& Lilja, J. (20I4). Kotimaisen tieteelliset lehdet ja avoin julkaiseminen: selvitys mahdollisista rahoitusmalleista. Tieteellisten seurain valtuuskunnan verkkojulkaisuja 2 . http://urn.fi/URN:ISBN:978-952-5995-09-I

Jubb M. (2016). Peer Review:The Current Landscape and Future Trends. Learn Publ. Wiley-Blackwell 29 (I), I3-2I. https://doi.org/I0.1002/leap. 1008

Kovanen, P. \& Saarelma, O. (2002). Tiedejulkaisun toimittajan moraalinen vastuu. Sakari Karjalainen \& Veikko Launis \& Risto Pelkonen \& Juhani Pietarinen (toim.): Tutkijan eettiset valinnat. Helsinki: Gaudeamus, 276-298.

Lariviére, V., Haustein, S., \& Mongeon, P. (20I5).The Oligopoly of Academic Publishers in the Digital Era. PLoS ONE, IO(6), e0127502-15. http://doi.org//0.| 37//journal.pone.01 27502

Lehtonen, Tuomas M.S. (20I I).Tieteellinen kustantaminen ja tieteen sisällöt. Tieteessä tapahtuu 29 (8), I-2. https://journal.fi/tt/article/view/4636

Le Goues, C. et al (2018). Effectiveness of Anonymization in Double-Blind Review. Communication of the ACM 6I (6) 30-33. https://doi.org/ | 0.1 I45/3208I57

Longva, L. et al (2017). Peer reviewing:A Private affair between the Individual Researcher and the Publishing Houses, or a responsibility of the University. Journal of Electronic Publishing 20 (I). https://doi.org/I0.3998/333645I.0020.103

Nature Neuroscience (1999). Pros and cons of open peer review. Nature Neuroscience, 2(3), 197-198. https://doi.org// 0.1038/6295

Niiniluoto, I. (20I3).Tiedeyhteisöä rakentamassa. Tieteessä tapahtuu 3 I (5) https://journal.fi/tt/ article/view/8636

Patomäki, H. (20I I). Julkaisuluokittelun politiikkaa: teknologia ideologiana. Politiikka 53 (4), 295-302. https://journal.fi/politiikka/article/view/60I27
Pölönen, J. (20I5). Suomenkieliset kanavat ja julkaisut Julkaisufoorumissa. Media \& Viestintä 38 (4). 237-252. https://journal.fi/mediaviestinta/article/view/62073

Raivio, K. (2006).Vertaisarviointi tieteellisessä julkaisutoiminnassa. Tieteessä tapahtuu 24 (7), I5-19. https://journal.fi/tt/article/view/56722

Ross-Hellauer,T., Deppe, A., Schmidt, B. (2017). Survey on open peer review:Attitudes and experience amongst editors, authors and reviewers. PLoS ONE I2(I2): e0 I893 I I. https://doi. org/| 0.137 I/journal.pone.01893 | |

Ross-Hellauer,T. (2017). What is open peer review? A systematic review [version 2; referees: 4 approved]. FI000Research 2017, 6:588. https://doi.org/ |0.12688/fI000research. I I 369.2

Sivula,A., Suominen, J.\& Reunanen, M. (20I5) "AI alkuperäisartikkeli tieteellisessä aikauslehdessä”. Uusien julkaisukäytänteiden omaksuminen ihmistieteissä 2000-luvulla. Kasvatus \& Aika 9 (3), |49-I7|. https://journal.fi/kasvatusjaaika/article/view/68543.

Schmidt, B., Ross-Hellauer, T., van Edig, X. \& Moylan, EC. (2018) Ten considerations for open peer review [version I; referees: 2 approved]. FI000Research 2018, 7:969 https://doi. org/| 0.12688/fI000research. I5334.|

Stančiauskas ,V. \& Banelytè,V. (20I7). OpenUP survey on researchers' current perceptions and practices in peer review, impact measurement and dissemination of research results. https://doi.org// 0.528I/zenodo.556157

Steinberg, P. E. (20I3). Kansainvälinen näkökulma tieteellisten seurojen julkaisutoimintaan. Terra 125 (2), 73-75.

Tennant, J. P., Dugan, J. M., Graziotin, D., Jacques, D. C., Waldner, F., Mietchen, D., ym. (20I7). A multi-disciplinary perspective on emergent and future innovations in peer review. F/000Research, 6, I| I|-53. http://doi.org/ |0.|2688/f| 000research. I 2037.|

Walker, R., \& Rocha da Silva, P. (2015). Emerging trends in peer review-a survey. Frontiers in Neuroscience, 9, 169. http://doi.org//0.3389/fnins.2015.00169 
Wang, P., \& Tahamtan, I. (2017). The state-of-the-art of open peer review: Early adopters.

Proceedings of the Association for Information Science and Technology, 54(I), 819-820. http://doi. org/l0.1002/pra2.2017.14505401170

Ware M. (2008). Peer Review: Benefits, Perceptions and Alternatives. Publishing Research Consortium. http://publishingresearchconsortium.com/index.php/prc-documents/prc-researchprojects/35-prc-summary-4-ware-final-1/file

Zaharie et al. (2016). Peer review motivation frames:A qualitative approach. European Management Journal 34, 69-79. https://doi.org/I 0. I0I6/J.EMJ.20I5.I2.004 
TIETEELLISTEN SEURAIN VALTUUSKUNTA

2019

Snellmaninkatu 13

00170 Helsinki

Finland

www.tsv.fi

Tel: +358 (0) 9228691

ISSN 2242-8011

ISBN 978-952-5995-16-9 